\title{
Analysing Challenges Facing Smallholder Farmers ANd Conservation Agriculture in South Africa: A System DYNAMICS APPROACH
}

\author{
Wolfgang von Loeper ${ }^{1 *}$, Josephine Musango ${ }^{2}$, Alan Brent ${ }^{3}$ and Scott Drimie $^{4}$ \\ ${ }^{I}$ School of Public Leadership, Stellenbosch University \\ ${ }^{2}$ School of Public Leadership and the Centre for Renewable and Sustainable Energy Studies, \\ Stellenbosch University \\ ${ }^{3}$ Department of Industrial Engineering and the Centre for Renewable and Sustainable Energy \\ Studies, Stellenbosch University \\ ${ }^{4}$ School of Public Leadership, Stellenbosch University
}

Accepted: November 2016

\begin{abstract}
Smallholder farmers in South Africa find it challenging to participate in the modern economy. Most of these farmers have limited access to credit and insurance, and to markets in which to sell their produce. This paper reviews ethnographic research data and argues that smallholder farmers struggle to take part in modern agricultural value chains in South Africa. System dynamics modelling is used to understand the dynamics relating to agricultural value-chain participants, and to determine whether the ethnographic research data is sufficient to answer the question as to which value-chain participants potentially have the largest impact on smallholder farmers. The modelling results show that banks may have the potential to trigger an impact on smallholder farmers' productivity that could then attract other value-chain industries to take part in efforts to support these farmers. Smallholder farmers could become a long-term viable and sustainable option for increasing food security in South Africa. However, this study has its limitations. The data used from existing ethnographic research, conducted by way of semi-structured interviews with valuechain participants, is limited and is not able to answer questions such as: (i) how much each industry is prepared to engage with smallholder farmers in the event of other industries being prepared to do the same; and (ii) how long it will take each industry to react to a willingness to engage. Ongoing research is required to extend the interviewee base and data in order to answer these questions and for the model to be completed and used for policy guidance.
\end{abstract}

Key words: smallholder farmers, agricultural value chains, system dynamics, modelling, food security

JEL: O2, 3

\section{$1 \quad$ Introduction}

Agricultural systems have a high impact on emissions, biodiversity and ecosystem services that humans depend upon. At the same time, the majority of the world's farmers - the small-scale farmers - are excluded from economic participation in modern food value chains. In a period during which output is required to double, it is predicted that agriculture will struggle with the consequences of climate change, with such consequences expected to globally reduce output by 10 to 15 per cent, slumping to 50 per cent in drier African regions (Nelson et al., 2009; Mitchell et al., 2007; Chassy et al., 2006; Res et al., 2010; Volakakis et al., 2014).

Agriculture globally, particularly in developing countries, is responsible for a large percentage of employment. Yet it is questioned whether agrifood systems are sustainable and equipped for a long-term transition that would sustainably supply the nourishment needed at the required volumes, while at the same time dealing with challenges from climate change and reducing the environmental impact of such change. There is not enough debate around these challenges and the role smallholder farmers play in this context and in ensuring food security. 


\subsection{Background to the issue of smallholder farmers and food security}

In a world where modern food systems are intertwined with global financial markets, there is little control over food. The reason for this is that food is traded as a commodity, which makes it subject to the vagaries of markets. This has a serious impact on food security (De Schutter \& Schutter, 2009). With reference to South Africa, Blignaut et al. (2014) argue that a transition to a green economy is increasingly taking place. However, research into sustainable agriculture in South Africa is limited, with there being a dearth of qualitative and quantitative evidence.

South Africa's agricultural and food system has been characterised by increasing concentration over the past decades, with farms becoming fewer and larger in size (Heijden \& Vink, 2013) and retailers attaining market dominance and achieving increased bargaining power (Andersson et al., 2013). At the same time, the financial sector has, on account of barriers, focused on delivering products to a few large farmers (Delgado, 1999). Although South Africa has a sophisticated agrifood system, 26 per cent of its population still lives in food-insecure circumstances (Labadarios et al., 2011; SANHANES-1, 2013).

Some of the most vulnerable in this system are smallholder farmers (SHFs) with poor access to infrastructure, inputs and markets, and who often have access to less than two hectares of land. SHFs need to function within an ever-growing and increasingly complex environment that is governed by the flow of funds controlled by banks, insurance companies, retailers, millers and traders. These "large value-chain participants" VCPs (large value-chain participants), whose growing market dissemination has assisted in concentrating power on their side of the South African agricultural complex, do not engage with SHFs. The exclusion of SHFs from modern agricultural value chains accordingly results in the economic exclusion of these farmers.

Evidence shows that an effectively producing SHF is seen as an essential route out of poverty (Page \& Slate, 2003). Small-scale farming occupies many more people than mechanised agriculture, while most SHFs farm with few external inputs and thus have less impact on the environment (UNCTAD, 2013; UNEP-UNCTAD, 2007; Altieri, 2009). They are thus good candidates for conservation agriculture or organic farming if a range of socio-economic barriers is addressed. Conservation agriculture is considered a more socially and environmentally just form of agriculture (Midgley et al., 2015) warranting a major investment of human and financial resources in sustainable agricultural systems (Blignaut et al., 2015; Modiselle, Verschoor \& Strauss, 2015; Pretty, 2002; Hendriks, 2013).

If there are economic benefits in developing SHFs, why is this not happening in South Africa?

\subsection{Research questions}

The following research questions are investigated in this paper:

1 What are the blockages in respect of selected value-chain partners from a perspective that SHFs face challenges in integrating into existing value-chain structures?

2 Who are the agents that form part of the value chains and where are they responsible for the shortfalls in providing a participatory platform for SHFs?

3 Where do policy and legislation contribute to blockages in value-chain participation for SHFs? What policy instruments do we need to provide for the development of an inclusive system for SHFs?

4 How much do individual value-chain participants (agents "Value-Chain Participants: Agents") influence one another in supporting or not supporting SHFs to participate in the economy?

5 How can the risk in respect of agents be reduced when engaging with SHFs?

6 For policy purposes, which of the agents have the greatest impact in supporting SHFs, that is, if policy can in fact be supportive of an agent?

7 How can exogenous variables that currently influence risk and engagement be changed in order to support value-chain industries' engagement with SHFs? 
Research Questions 1 and 2 were arrived at through ethnographic qualitative participant research using semi-structured interviews (Von Loeper, 2015; Midgley et al., 2015), with the resultant data being used for the modelling. System dynamics modelling was then utilised to answer Research Question 3 to 7.

\section{Literature review}

\subsection{Smallholder agriculture and its impact on food security}

Food security has a long history in South Africa (Hendriks, 2014). Its genesis can be found in the diverse livelihood strategies of indigenous communities before the advent of colonialism. The arrival of the Dutch East India Company in 1652 heralded an era of conflict, conflict that continued down the centuries with farmers settling across the country and the rise of foodproduction needs in the mining towns in the 1860s. Friction between black and white farmers, as Hendriks (2014) illustrates, resulted in the Natives Land Act of 1913 and the creation of the Bantu homelands in 1951. Together, these effectively resulted in a dualistic farming sector, with white farmers having most of access to land and subsidies.

Since the advent of democracy in 1994, the ideal has been to reverse the inequalities created under colonialism and apartheid through land reform and support programmes for black emerging farmers. While the government acknowledges that a host of these projects have not had the intended outcome, Altman, Hart and Jacobs (2010) argue that the government's focus on emerging commercial farmers has given little attention to subsistence farming and SHFs. Hendriks (2014) argues that the vast majority of land redistribution has been unproductive and non-functional and that SHFs still produce a quarter of what commercial farmers produce. It can thus be argued that there is significant untapped potential among SHFs. In the words of Delgado (1999): "Smallholder agriculture is simply too important to employment, human welfare, and political stability in subSaharan Africa to be ignored."

In Southern Africa, the issue of food security has continued to give rise to increasing challenges over the last 20 years. Love et al. (2006) argue that it is not logical to resolve food-security problems by focusing on increasing the production of commercial farmers. Kirsten and Van Zyl (1998) argue that small-scale farming is not backward or non-productive, but can be as viable, profitable and efficient as large-scale farming. However, the South African government is faced with the tremendous tasks of lowering transactional costs and reducing the number of barriers facing SHFs (Kirsten \& Van Zyl, 1998). These costs and barriers, which Kirsten and Van Zyl (1998) argue include access to land, credit, insurance, information, and markets, are the focus of this paper.

About three-million households in South Africa are engaged in subsistence agriculture (Aliber \& Hart, 2009; Altman et al., 2010; Biénabe, Vermeulen \& Bramley, 2011), while SHFs number about 250000 farmers (Aliber \& Hall, 2012). Both groups receive limited attention from policymakers (Altman et al., 2010). According to Baiphethi and Jacobs (2009), there is a significant need to increase the productivity of SHFs in order to ensure long-term food security, as smallholder production increases the food supply within households and therefore stifles the effect of commodity and food prices on these households while at the same time improving food security.

\subsection{The impact of smallholder agriculture on ecosystems}

At no time in history has agriculture had such a great impact on the environment and ecosystem services (Pretty, 2008; Matson \& Vitousek, 2006; Fischer et al., 2008; Perfecto \& Vandermeer, 2008). Covering a third of the planet's surface (Pengue et al., 2013), agriculture has resulted in disturbed ecosystems (Pretty, 2008; Robertson \& Vitousek, 2009; Ewers \& Didham, 2008), land degradation (Pingali \& Pardey, 2010), loss of biodiversity (Letourneau et al., 2011; Bernstein, 2013; Lithourgidis et al., 2011) and topsoil erosion of 10-million hectares annually (Pimentel et al., 1995), which is 100 times faster than would occur naturally (Reusser, Bierman \& Rood, 2015). 
Agriculture uses 70 per cent of our freshwater (UNEP, 2011), is energy-hungry, emits 25 per cent of global carbon dioxide $\left(\mathrm{CO}_{2}\right)$ (Adhya, Sharma \& Gogoi Kumar, 2009; Smith et al., 2014; Cleveland \& Kaufmann, 1986; June \& Günther, 2000), and, while occupying five times more land than any other land use, is arguably the largest contributor to biodiversity loss, making it altogether the greatest human impact on "planetary boundaries" (Rockström et al., 2009).

The yield gap between conventional farming and organic farming, especially with proper diversification practices, is smaller (8-9 per cent) than initially estimated (Ponisio et al., 2014). Composts in Ethiopia have increased yields by two to three times, outperforming conventional fertilisers (Edwards, 2004). In the United States of America (USA), organic farming achieves comparable or better yields during droughts (Rodale Institute, 2014) when compared with conventional farming (Delate \& Cambardella, 2004; Lim, 2002). Using one tonne less of synthetic nitrogen fertiliser results in 5.2 to 7.6 tonnes less carbon emissions equivalent (Wood \& Cowie, 2004). Conventional farming is responsible for three- to five-million cases of pesticide poisoning every year (UNEP 2011:8) and conventional-tillage farming practices increase soil-based $\mathrm{CO}_{2}$ respiration, which is exacerbated by global warming (Raich \& Schelsinger, 1992; Schlesinger \& Andrews, 2000). Consequently, conventional tillage gives rise to almost 14 times more carbon emissions than no-till (Reicosky, 1997). This has resulted in soil organic carbon emissions of 50Pg due to tillage (Topp et al., 2013).

Organic agriculture uses two to seven times less energy than conventional agriculture (Medard, 1981; Cormack \& Metcalfe, 2000) and sequesters 5 to 15 per cent of greenhouse gas emissions (Lal, 2004; Lal, Negassa \& Lorenz, 2015). Tropical agroforestry systems can store up to 258 tonnes of carbon per hectare (Lasco et al., 2001), sequestering 6t/ha of carbon annually (Schroeder, 1991), or, otherwise, as Hepperly (2003) shows, 4t/ha. Coghlan (2006) even argues that trees planted by local farmers in the Sahel can push back the desert.

Smallholder farms occupy 1000 times more people than mechanised agriculture (UNCTAD, 2013), while the IAASTD (2009) reports that 70 per cent of sub-Saharan Africa's food supply comes from SHFs. Africa's SHFs mostly engage in low-external-input (LEI) and organic agriculture (UNEP-UNCTAD, 2007) and utilise small parcels of land with high genetic diversity, altogether resulting in much less of an environmental impact (Altieri, 2009; Altieri, FunesMonzote \& Petersen, 2011) than high-external-input (HEI) agriculture, as practised by commercial farmers (Altieri \& Nicholls, 2005; Fischer et al., 2008; Diaz \& Rosenberg, 2008).

Organic farming is ideally suited to smallholder farming because of its reliance on naturally available fertility inputs, because it requires less financial investment, because of its approach to diversity, and because of its resilience to plant stress (UNEP-UNCTAD, 2007). Thus SHFs are less dependent on large multinational supplier corporations (Altieri et al., 2011), enabling developing nations to free themselves of supplier imports. Additionally, SHFs produce food "more" organically, which arguably has higher nutritional value (Chassy et al., 2006; Res et al., 2010; Huber et al., 2011; Rodale Institute, 2012; Volakakis et al., 2014).

Globally, the IAASTD estimates that 90 per cent of farms worked by smallholders are less than two hectares in size (IAASTD, 2009). Similarly, the Food and Agricultural Organization estimates that, globally, 92.3 per cent of farms can be defined as "small farms", with 83 per cent of these being smaller than two hectares in extent (FAOSTAT, 2014). South Africa, in contrast, has an average farm size of 1400 hectares (Ramaila, Mahlangu \& Du Toit, 2011). With 0.3 per cent of its population involved in commercial farming, the country has more of a developed-nation structure than that of a developing country (Heijden \& Vink, 2013).

Environmental degradation, disturbed ecosystems, loss of topsoil, modern human diseases, and significant $\mathrm{CO}_{2}$ emissions, all exacerbated by conventional agriculture, give rise to the question whether modern, industrialised, large-scale farming systems have the capacity to sustain long-term food security. This, in turn, leads to the question whether SHFs are not a better option for guaranteeing long-term and sustained food security, in ensuring less environmental degradation, and, as Wiggins (2009) argues, in potentially producing more calories per hectare than large farms. 


\subsection{Shortfalls in extension services for SHFs in South Africa}

Extension services for SHFs are a concern for the United Nations (Love et al. 2006). Extension officers in KwaZulu-Natal in South Africa only visit SHFs once a year, and the educational levels of such officers remain low (Ortmann \& King, 2007). With reference to the North West province of South Africa, Ngomane, Thomson and Radhakrishna (2002) note another challenge: staff changes in the provincial Department of Agriculture have created instability in the delivery of extension services, with the result that the administrative body finds it difficult to implement the regularly changing political commitments made by Members of the Executive Council (MECs).

Ngomane et al. (2002) also argue that extension-staff shortages are the result of the way in which resources are allocated by the national Department of Agriculture in South Africa: 92 per cent of the national budget was, according to them, spent on a ministry staff complement of 11000 , of which only 1200 were extension staff, thus stretching the ability of the latter to serve South Africa's SHFs. While budgets have trebled over a 20 -year period, the vastness of the administrative apparatus swallows the largest portion of the budget, with extension services in South Africa reaching only 11 per cent of SHFs (Aliber \& Hall, 2012).

An investigation of the Department's focus on a few select projects that benefit only a limited number of SHFs revealed that targeting of agriculturally active black households by extension services had a mere 1.8 per cent reach (Aliber \& Hall, 2012). Aliber and Hall (2012) criticise the ratio of extension to non-extension personnel, arguing that the government departments concerned make poor use of resources at their disposal and do not understand the needs - or indeed know the whereabouts - of their primary clients (Aliber \& Hall, 2012).

Baiphethi and Jacobs (2009) argue that, to bolster subsistence agriculture, investment in extension services needs to be improved. For Aliber and Hall (2012), however, it is concerning that, notwithstanding the small impact that extension currently has, such service uses up over half of support budgets at the provincial level. This, they indicate, raises the question as to what it would cost to achieve an appreciable difference (Aliber \& Hall, 2010).

\subsection{Challenges encountered by SHFs in accessing markets}

A major reason why SHFs with surplus production remain trapped in poverty is the lack of access to markets (Magingxa, Alemu \& Van Schalkwyk, 2009). Almond and Hainsworth (2005) argue that field extension agents are ill-informed about local markets and often do not provide the necessary training and assistance so that SHFs can gain access information about markets. These authors maintain that government should leverage the private sector and facilitate access to markets by using existing value-chain infrastructure (Almond \& Hainsworth, 2005).

Based on two cases, Ortmann and King (2007) illustrate that access to high-value markets poses considerable challenges for rural farmers, and that infrastructure investment is critical in reducing these types of transactional costs. However, they also maintain that cooperation among producers can facilitate access to markets while increasing bargaining power. They highlight that government should play a role in assisting these group actions through coordination and start-up funding (Ortmann \& King, 2007).

Biénabe et al. (2011) indicate that another opportunity for SHFs to access markets is through "quality food" and "high-value food" production. High-value crops and organic crops, they argue, are labour-intensive and require considerable attention during production. These crops, they maintain, are ideal for production by SHFs. They criticise certification schemes driven by the dominant retail sector in South Africa as onerous and as favouring large-scale producers with the capacity to conform to such schemes (Biénabe et al., 2011).

Mahlogedi and Thindisa (2014) take the concept of high-value produce a step further by arguing that agroprocessing has the capacity to improve the livelihoods of SHFs owing to the postprocessing value that is added to the product. However, they also indicate that this requires sufficient human and social capital to reside with the farmer-entrepreneur, as well as low transaction costs to encourage a willingness to engage own resources (human and social capital) and the market (Mahlogedi \& Thindisa, 2014). 


\subsection{Challenges faced by SHFs in accessing financial markets}

As Delgado (1999) points out, barriers arise primarily because market failures prevent solutions, which might include microcredit, from reaching rural African populations. Kirsten and Van Zyl (1998) concur and argue that credit availability, among others, is either imperfect or missing as an accessible service for SHFs. In contrast, Ortmann and King (2007) argue that high transactional costs in value-chain market participation are also due to language issues - in two regions in KwaZulu-Natal, it was found that only 36 per cent of SHFs spoke English in a context where this is the lingua franca. Small-scale producers in South Africa indicated that access to credit was the major reason why they would not be able to attain access to water and undertake irrigation (Bryan et al., 2009).

Kirsten and Van Zyl (1998) maintain that access to insurance is either imperfect or absent. For example, many smallholder households in Lesotho do not have any form of insurance (Ziervogel, 2004). Because insurance is largely unaffordable in developing countries, only 1 per cent of households in low-income countries and 3 per cent of households in middle-income countries have catastrophe coverage (Linnerooth-Bayer \& Mechler, 2007). Linnerooth-Bayer and Mechler argue that, owing to climate change and associated risks, insurance for SHFs will become important.

\subsection{Highlights of the literature review}

Baiphethi and Jacobs (2009) indicate that 90 per cent of food for households emanates from markets - with an increased proportion of income being spent on food - while subsistence production and public programmes only constitute up to 10 per cent of household food sources. The best way of enhancing access to food is through food production by subsistence farmers and SHFs, which, because such access is direct, will drive down food prices (Baiphethi \& Jacobs, 2009).

Aliber and Hall $(2010,2012)$ argue that, instead of considering the base of smallholder farming as a source for building emerging, black commercial farming enterprises and rather than focusing on a few expensive projects, efforts to combat massive unemployment and poverty should leverage the large numbers of subsistence farmers and SHFs in South Africa and use land-reform efforts to increase smallholder-farming viability. Creating new, large-scale, emerging commercial farming enterprises is counterproductive and efforts should focus rather on regions with existing SHF concentrations and on investment in infrastructure and other conditions in order to create a climate of success, adaptation and diversification. According to Aliber and Hall $(2010,2012)$, this includes: new and more refined market linkages with broader access to supermarkets; decentralised agroprocessing that supports small-scale production; the promotion of land-rental markets; and a more participatory approach.

However, SHFs in South Africa struggle to survive and to participate in food value chains, which currently maintain a flow of capital funds to a few selected and preferred large producers. Not being able to participate in these value chains, and in many cases not being able to meet their own food needs, means exclusion from capital markets and a general struggle for economic survival. Moreover, rural areas continue to be stigmatised as regions of low opportunity for young people. Ortmann and King (2007) effectively sum up the challenges facing SHFs in South Africa as being: (i) low levels of education and literacy; (ii) no access to technology; (iii) insecure land tenure; (iv) high transaction costs (i.e. no access to information and communication, as well as poor roads and long travel distances); (v) no access to credit and insurance; (vi) no access to inputs and services; (vii) no access to markets; and (viii) missing support systems, such as socially organised co-ops and extension services.

\section{Research methodology}

\subsection{Research scope}

While the challenges that face SHFs are multiple, this paper focuses on investigating the complexities of the value chain (i.e. points 3, 4, 5, 6 and 7 in Section 1.2). The principle question 
is: Where in the value chain do the nerve points lie that create the challenges, and how can one overcome them in order to create an economically inclusive scenario for smallholder farming?

For the purposes of this research, we focus on inspecting the relationships between the VCPs (banks, insurers, retailers, traders) as illustrated in Figure 1 and SHFs in general. Value chains need to be understood as manufacturing or service processes that are organised into a system of input, transformation process and output that involves the consumption of resources (such as money, labour, material, equipment, buildings, land, administration and management) in order to produce a product (Cambridge University, n.d.). These value chains are context-specific, which limits the generalisation of this analysis, although the insight gained is still deemed useful.

Figure 1

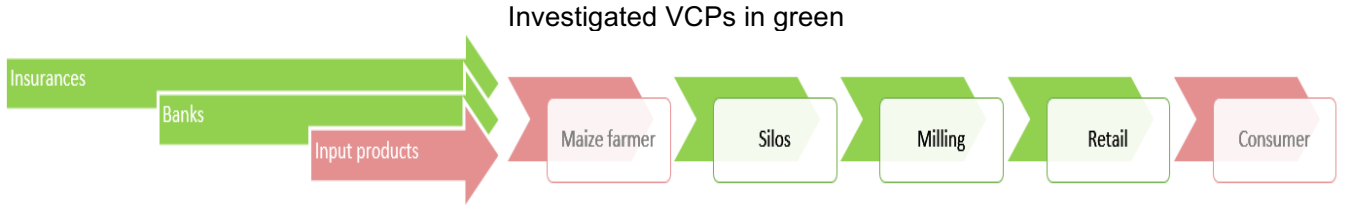

\subsection{The modelling approach}

Blignaut et al. (2014) found that research into sustainable agriculture and smallholder farming in South Africa was lacking in both supporting qualitative and quantitative evidence. Their subsequent research was aggregated into a system dynamics model used for building scenarios for policy development around research on sustainable cropping systems (Blignaut et al., 2015; Midgley et al., 2015).

However, this system dynamics model did not investigate the dynamics and complexity of the challenges facing SHFs in participating in modern agricultural value chains. These challenges, we argue, require investigation of the dynamics and complexities that exist among individual industries found in agricultural value chains in South Africa. In this paper, system dynamics modelling is therefore utilised to show these dynamics and the potential feedback within such system which policy could use to initiate scale and accelerate a participatory framework for SHFs.

Meadows (2009) describes system dynamics modelling as a tool with which to test model constructs and potential scenarios, and indicates that such modelling has the capacity to "explore possible futures and ask 'what if' questions". Meadows (1989) also states that system dynamics modelling assumes that things are interconnected and that the world is made up of levels, rates, feedback loops, and non-physical information that flows on the basis of non-linearities and delays.

Given the dynamic nature of the research questions, it is argued that system dynamics is an appropriate method to employ in the present study. It has the capacity to illustrate causal relations, to model these into stock levels, and to relate them to feedback loops and information flows that are not always physically evident without simulation. Additionally, the subject investigated reveals many economic dynamics coupled with agro-socioecological complexities that system dynamics is capable of capturing.

\section{The system dynamics value-chain model}

\subsection{Endogenous and exogenous variables}

As a first step in developing the model, the endogenous and exogenous variables that must form part of the model were considered as part of setting the model's boundaries.

This model is not exhaustive and does not comprehensively capture the full dynamics of all SHF challenges. For the purposes of answering our research questions, we have focused on the most important and largest economic actors and agents in South Africa's agricultural value-chain system as input variables in this model. We have therefore excluded variables of lesser concern, which include variables that are nonetheless important to the challenges SHFs face, such as field 
extension, tertiary education, consumers, non-governmental organisations (NGOs), government organisations, and others.

Table 1

Key variables in the model

\begin{tabular}{|c|c|c|}
\hline Variable & Unit used & Scale \\
\hline Banks & Eng (engagement) & 5 to -5 \\
\hline Insurance companies & Eng (engagement) & 5 to -5 \\
\hline Maximum engagement & Eng (engagement) & 5 \\
\hline Maximum disengagement & Eng (engagement) & -5 \\
\hline Serving & Per cent & $1-100$ \\
\hline Not serving & Per cent & $1-100$ \\
\hline Initial serving & Per cent & $1-100$ \\
\hline Rates of influence & Per cent & $1-100$ \\
\hline Risk & Stock & $0-100$ \\
\hline SHF productivity & Stock & $0-100$ \\
\hline Retailers \& traders & Eng (engagement) & 5 to -5 \\
\hline Cooperatives, logistics and compliance & Eng (engagement) & 5 to -5 \\
\hline Cash from products & DMNL & 5 to -5 \\
\hline Initial risk & DMNL & 50 \\
\hline Initial productivity & DMNL & 50 \\
\hline
\end{tabular}

Table 2

Exogenous variables

\begin{tabular}{|c|}
\hline Initial risk \\
\hline Initial productivity \\
\hline Initial serving \\
\hline Access \& National Credit Act \\
\hline Access to fertile land \\
\hline Access to education \\
\hline I-initial serving \\
\hline R-initial serving \\
\hline B-initial serving \\
\hline Table of SHF productivity influence on $\mathbf{R}$ \\
\hline Table of I influence on B \\
\hline Table of R influence on I \\
\hline Table of R influence on B \\
\hline SW 1, 2, 3 + Available SW \\
\hline
\end{tabular}

\subsection{Time horizon}

Because information flow from one industry to another does not occur on a daily basis, it is assumed that, within a few months, the information from one industry's or agent's engagement or non-engagement will penetrate through to other value-chain participants.

The time unit that is chosen is "months", and the simulation time horizon is 30 months.

\subsection{Causal-loop diagram (CLD)}

Figure 2 represents a CLD that is central to this study. Four reinforcing loops are represented in the relationship between banks, insurance companies, and the inherent risk of these two in engaging with SHFs. The business of banks and insurance companies hinges entirely on reducing risk, and, as such, the relationship as illustrated in Figure 2 shows strong dependency of one industry on the other when working with SHFs. 
Figure 2

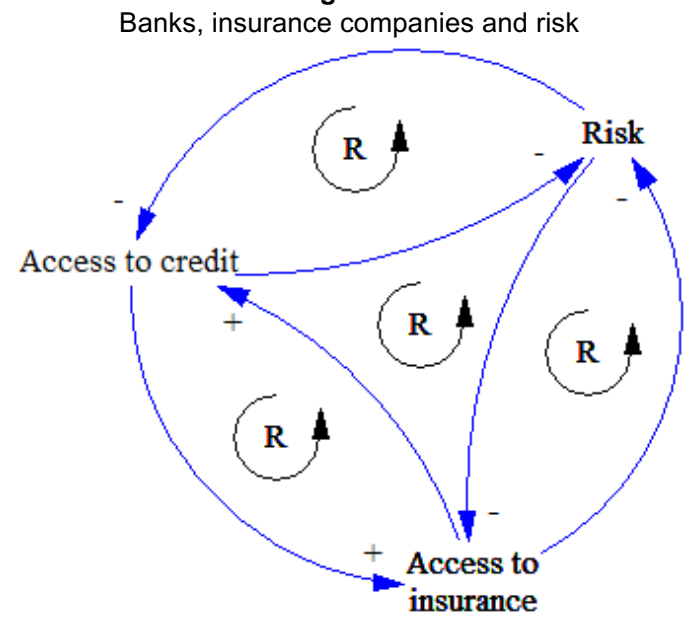

It is expected that a slight reduction in risk will entice both banks and insurance companies to more readily extend credit to SHFs and provide them with insurance. Further, the more that banks are prepared to render services to SHFs, the more that insurance companies will be prepared to join in, and vice versa.

Two major industry players, retailers and traders, which are characteristically exogenous to the above reinforcing loop, influence such loop. In other words, in the internal play between banks and insurance companies, their own activity can reinforce the effect on risk. This, however, might just as well be a vicious reinforcement - which is currently the case, as research has shown that both banks and insurance companies do not supply product to SHFs. Nevertheless, retailers and traders can influence this compoundable effect exogenously.

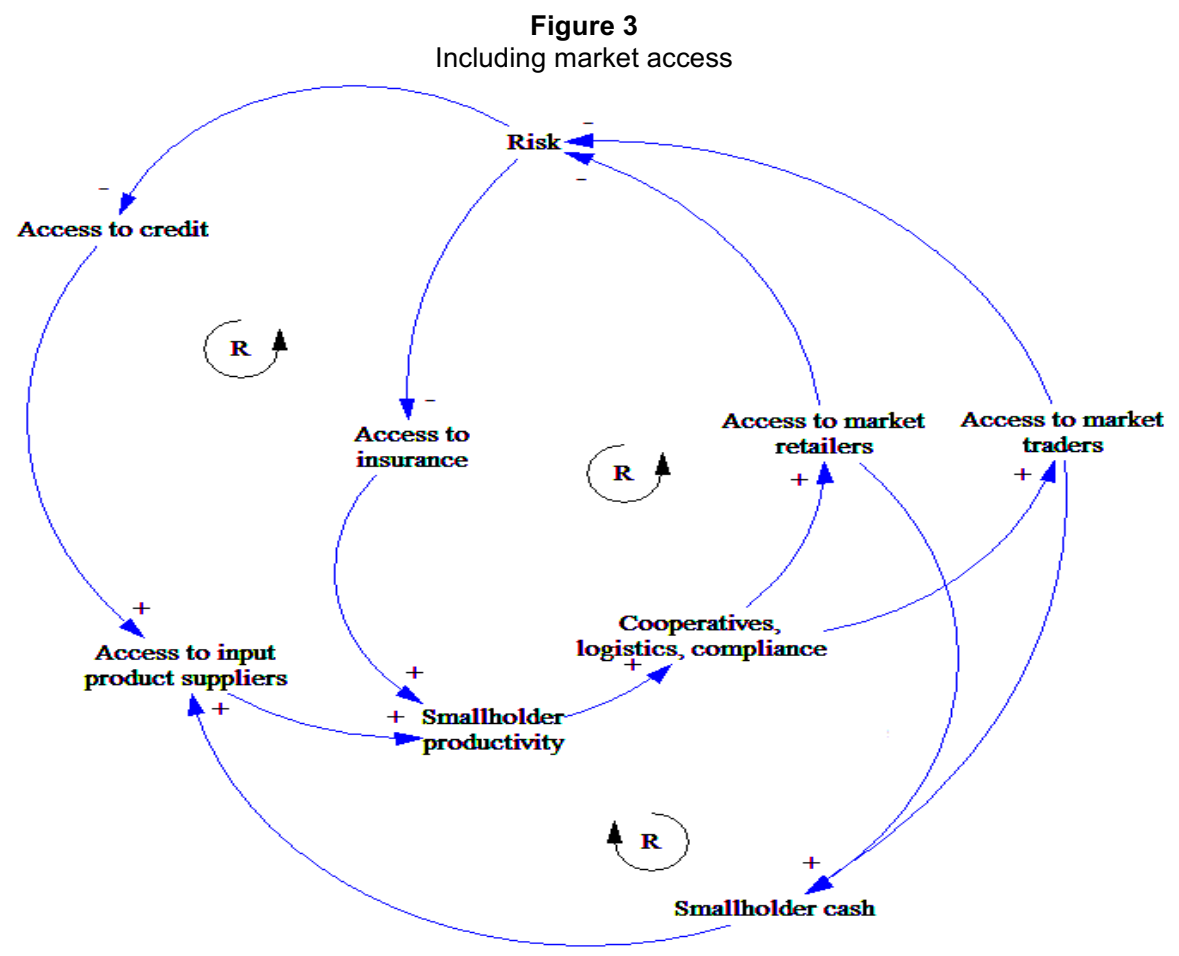


Retailers and traders were investigated endogenously. Increased SHF productivity will entice retailers and traders to increase their purchases from SHFs. The SHF relies not only on cash from these two sectors in the form of income from crops, but also on cash from banks to fund input products and on insurance for crop failures.

In Figure 3, cooperatives, logistics and compliance are included as a hurdle for SHFs and retailers/traders in engaging with one another in order to resemble the limitations due to transactional costs. However, the CLD in Figure 3 shows that the greater SHF productivity is, the more logistics and compliance will be prepared to render services and the more likely it is that SHFs will form cooperatives so as to gain bargaining power against the forces of logistics, compliance auditors, traders and retailers. The more productivity there is, and the more logistics and compliance there is, the more the market will buy from the SHF, which, in turn, will pay more cash to the SHF. This will result in the SHF using the cash to buy more input products and will again drive up the SHF's productivity until it reaches a plateau.

We have added exogenous variables to the logic of these causal loops (see Figure 4). Such variables are essential to the productivity of the SHF and critically influence the way banks and insurance function within legislative and legal systems in South Africa (see grey variables).

Figure 4

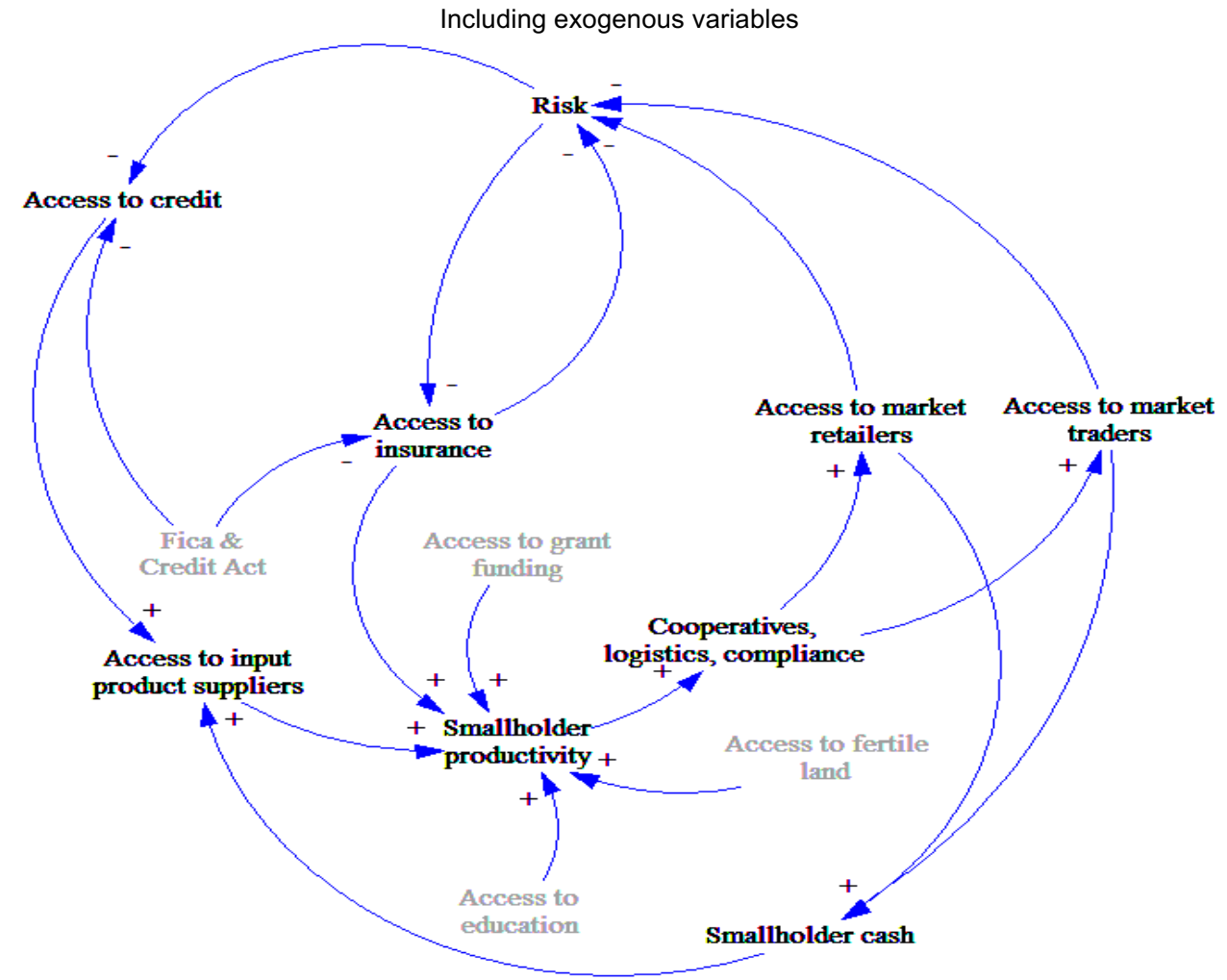

These exogenous variables include the Financial Intelligence Centre Act (FICA) and the Credit Act, both of which place obligations on banks and insurance companies to keep records and to lend and insure based on fair standards. However, these variables are very onerous in South Africa and result in huge costs in the case of small clients like SHFs.

Access to land, education, and grant-funding are critical in order for SHFs to start their businesses. Without land and education, nothing will grow; and, without grant-funding, the SHF will struggle to obtain the proper equipment and will subsequently grow productivity more slowly. We also assume that the more access an SHF has to both grants and education, the less he or she 
will require it in future. Consequently, the government will need to spend less money on more productive SHFs as the years pass.

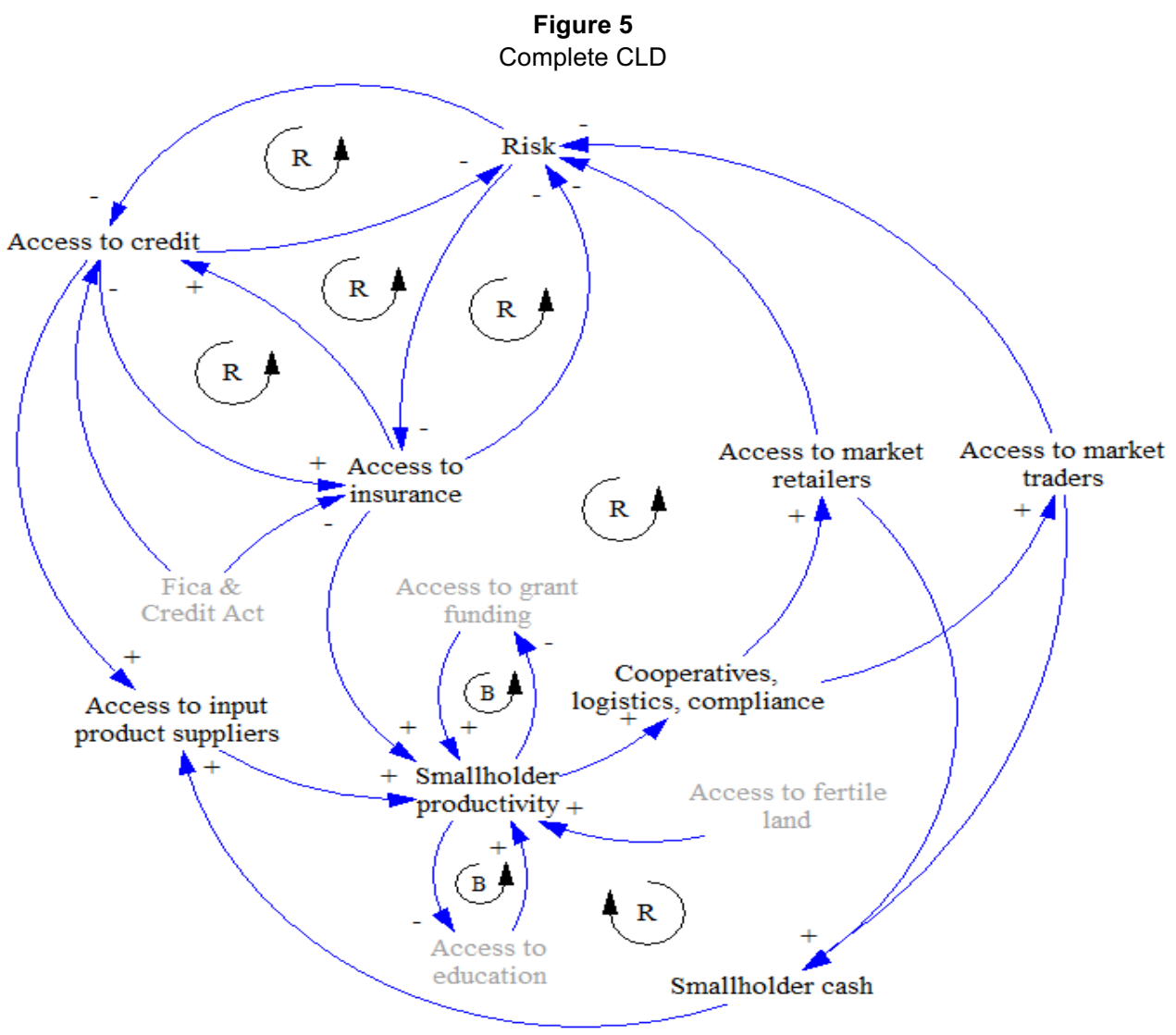

In this case study, we experiment with different scenarios, testing possible policy in working with banks and insurance companies and the effect on risk, and possible policy in working with traders and retailers and the effect on risk, in order to discover which has the biggest impact with the least effort.

\subsection{Stocks and flows}

From the CLD, it can be seen that banks, insurance companies, retailers and traders influence the level of risk that each one experiences when engaging with SHFs. However, the risk can be positively or negatively influenced by any of the aforementioned sectors. Risk (R) is thus represented as a stock, from which Figure 6 flows $(\mathrm{B}=$ banks and $\mathrm{I}=$ insurance companies).

In the case of Figure 6, financial institutions influence each other's activity; in other words, the more that banks engage with SHFs, the more that insurance companies will also do so. This is shown by the variable "I influence on B serving" and represents the reinforcing loops in Figure 2 (Banks, insurance companies and risk). We have made use of tables, which are detailed in the appendices, to influence and control the serving of banks (B-Serving), and have then added switches - in this case, SW3 in Figure 6, which is a control mechanism to interrupt the influence of risk impacting the banks' willingness to serve. We have introduced such switches for scenariobuilding and for purposes of testing. 


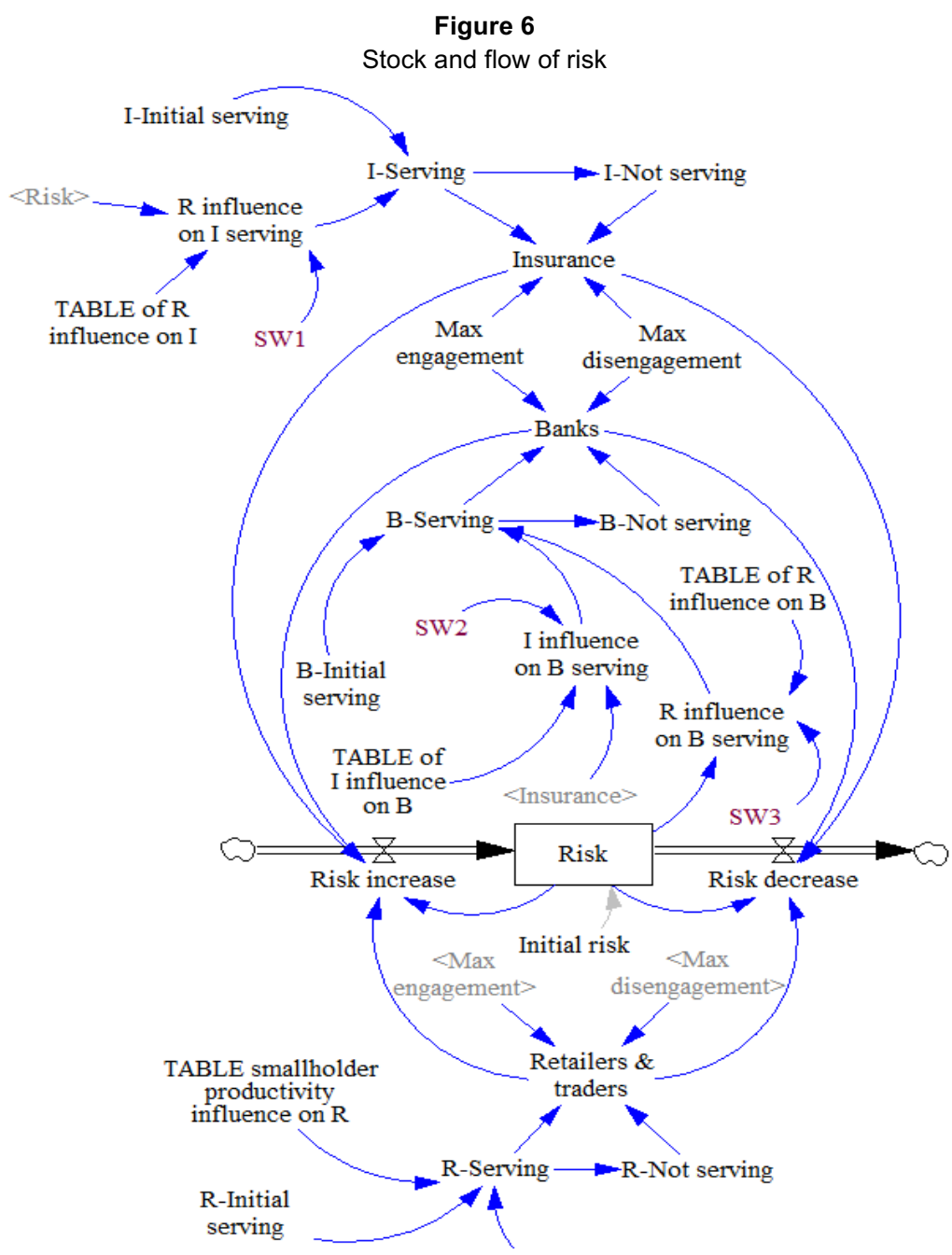

The bottom portion of Figure 6 shows that, if retailers, for example, reduce the risk for other institutions by buying from SHFs, the stock of risk reduces and, with the reduced stock of risk, both financial institutions, namely the banks and insurance companies, are influenced to serve SHFs. The more that this occurs, the more that the stock of risk is reduced again, which, in turn, influences both insurance companies and banks to engage even more.

\subsubsection{Smallholder productivity}

The level of engagement of banks, insurance companies, retailers, traders, and existing cooperatives, logistics and compliance influences SHFs' productivity. Only if the last three mentioned are in place will retailers engage with SHFs, which, in turn, drives cash to SHFs, and this also influences their productivity.

It was therefore decided to introduce a second stock, namely "smallholder productivity". Available cash, cooperatives, logistics and compliance influence the level at which SHFs can be productive. However, insurance companies, banks, retailers and traders (indicated in grey in Figure 7) are endogenous variables that influence the level of risk that exists for these institutions in engaging with SHFs. A switch was also introduced here ("Available SW") in order to be able to switch off availability of cooperatives, logistics and cash to the SHF. 
Figure 7

Stock and flow of smallholder productivity

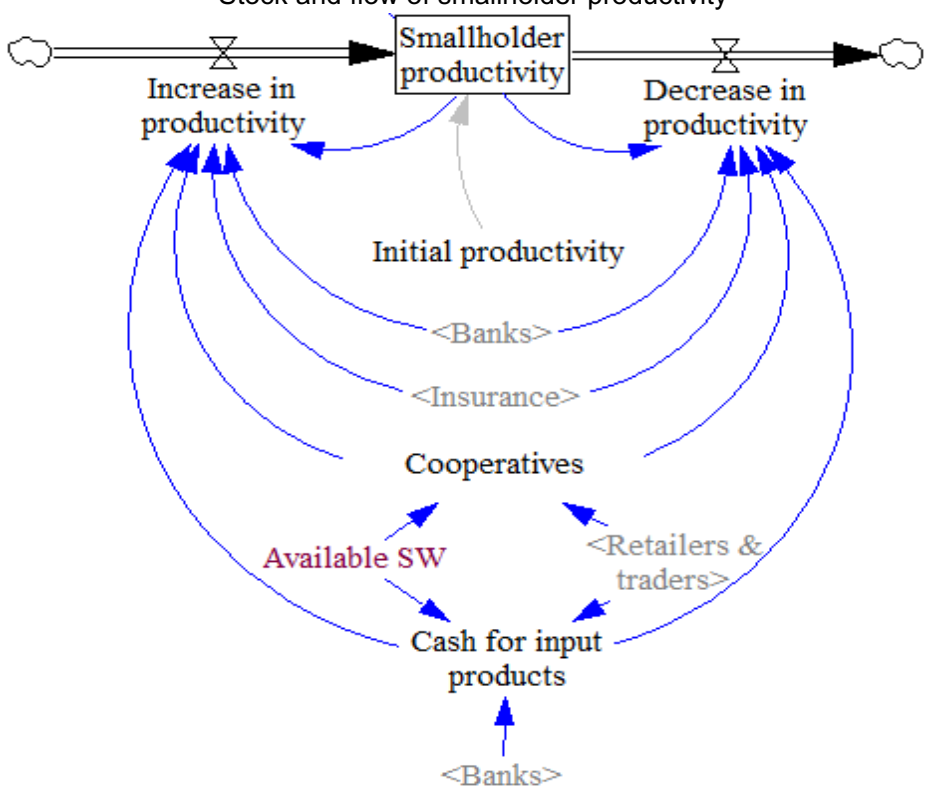

It is therefore critical to also illustrate here how the above two stocks that have been detailed influence each other, and where they link up. This is explained below.

\subsubsection{Risk and smallholder productivity}

The extent of retailer engagement influences the number of retailers and traders, which, in turn, influences risk. Figure 8 shows that, should the SHFs be productive, the market side of the valuechain agents (the traders and retailers) will serve SHFs by purchasing their produce. This, again, will reduce risk and increase the preparedness of banks and insurance companies to serve SHFs.

Figure 8

Risk and smallholder productivity

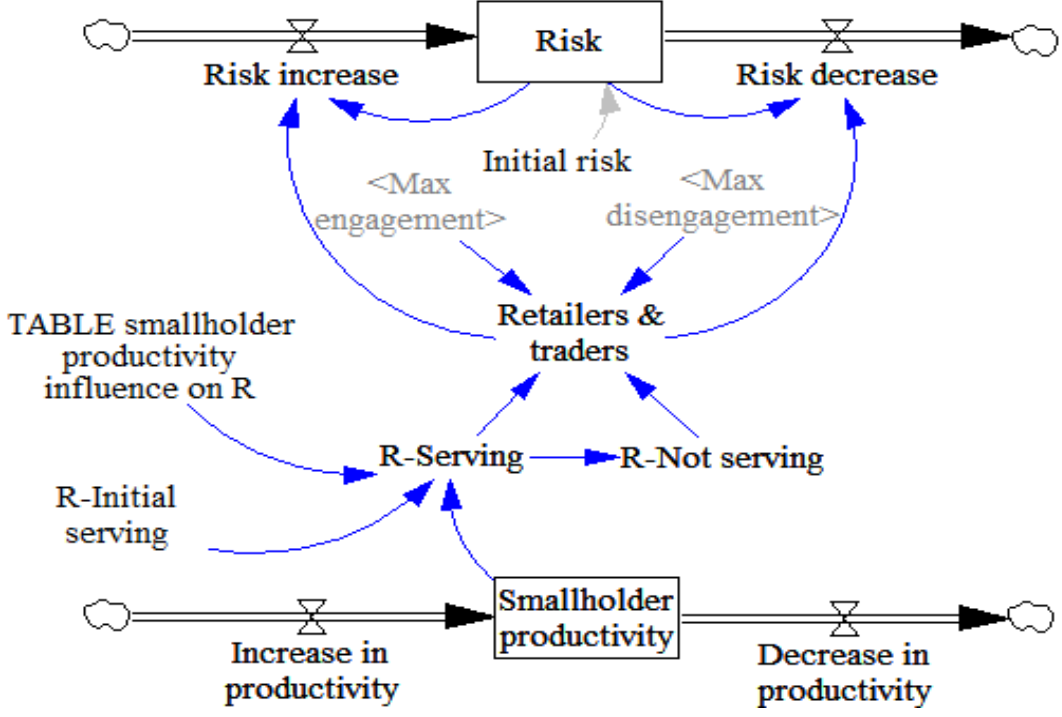




\subsection{Validation - extreme-condition testing}

An extreme-condition test was utilised to validate the structure of the model.

Figure 9

Validation (minimum \& maximum)
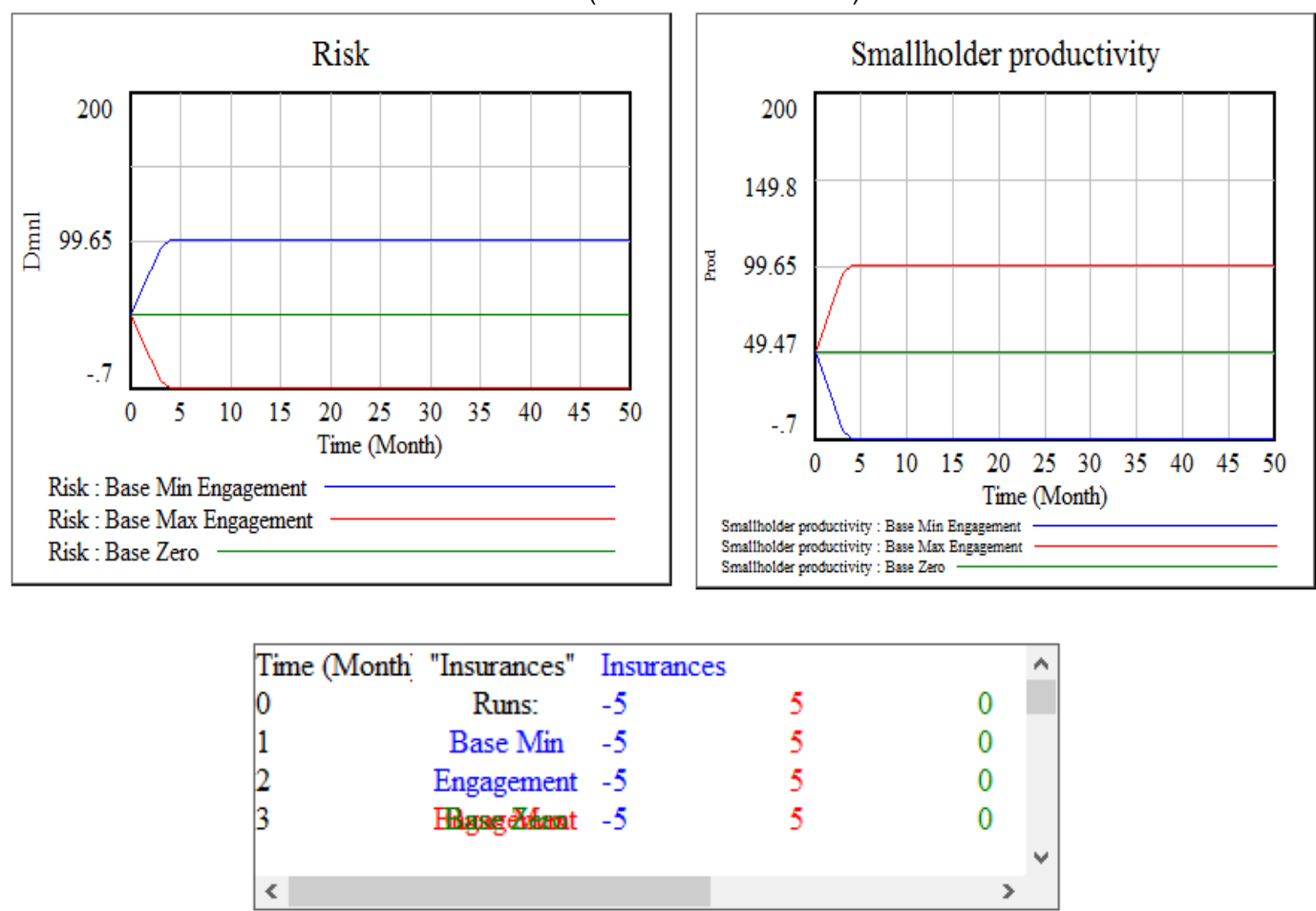

\begin{tabular}{|llllll|}
\hline Time (Month "Banks" Runs: Banks & & & $\wedge$ \\
0 & Base Min & -5 & 5 & 0 & \\
1 & Engagement & -5 & 5 & 0 & \\
2 & Base Max & -5 & 5 & 0 & \\
3 & Engagement & -5 & 5 & 0 & \\
4 & Base Zero & -5 & 5 & 0 & $\vee$ \\
$<$ & & & & \multicolumn{2}{c}{\rangle} \\
\hline
\end{tabular}

\begin{tabular}{|c|c|c|c|c|c|}
\hline Time (Month & "Retailers \& & \multicolumn{3}{|c|}{ "Retailers \& Traders" } & $\wedge$ \\
\hline 1 & Traders" & -1.04827 & 1.04827 & 0 & \\
\hline 2 & Base Min & -2.20643 & 2.20643 & 0 & \\
\hline 3 & Engagement & -3.48599 & 3.48599 & 0 & \\
\hline 4 & HAgrge Xffant & -4.89969 & 4.89969 & 0 & \\
\hline 5 & HAgreg Xfant & -5 & 5 & 0 & $\checkmark$ \\
\hline$<$ & & & & & \\
\hline
\end{tabular}

The simulation starts at a risk of 50 out of 100 and 50 out of 100 for farmers being productive, while the other half is unproductive. This results in a form of "stalemate" (green) among banks, insurance companies and retailers, all of which show zero interest in changing their level of engagement with SHFs.

The more the risk drops below 50, the more banks and insurance companies will engage with SHFs, and, the more these engage with SHFs, the more the SHFs will become productive - in 
which case the more the market (retailers and traders) will engage with SHFs. Each of these three sectors can have a maximum level of engagement with SHFs of 5, or a minimum level of engagement of -5 , in which case all of these three value-chain sectors will avoid any form of engagement with SHFs.

Running the model to the extreme of its three exogenous input values, namely "I-Initial serving", "B-Initial serving", "R-Initial serving", gives the expected results in the "Risk" and "Smallholder productivity" graphs, as well as the three sectors" maximum (red) and minimum (blue) values of engagement. In the case of the "Retailers \& traders" table, it is expected that there will be a delay before reaching the minimum and maximum values, because this variable is not influenced by a compounding effect of risk, which insurance companies and banks are.

When synthesising the model between the values shown above, it is clear that, in respect of various combinations and steps of input-value levels, the model behaves as expected.

\subsection{Model scenarios}

Three variables, namely the initial readiness of banks, insurance companies and retailers/traders to serve and engage with SHFs, were selected for scenario analysis in this paper. The scenarios aim to explore the question: How much do the individual value-chain participants influence the productivity of SHFs, and how much do they influence themselves in increasing or decreasing readiness to engage with SHFs? On a scale of 0 to 100 per cent, these three sectors can fully engage (100 per cent), or may not engage at all (0 per cent), with SHFs.

However, data from the interviews and grounded theory (Von Loeper, 2015; Midgley et al., 2015) show that there is currently no engagement with SHFs on the trader and retailer side, while 33.3 per cent of banks have some form of engagement with SHFs. As this paper does not include insurance companies for modelling purposes, it is also assumed that 0 per cent of such companies currently work with SHFs. This combination is what is used in the baseline scenario.

Figure 10

Baseline scenario

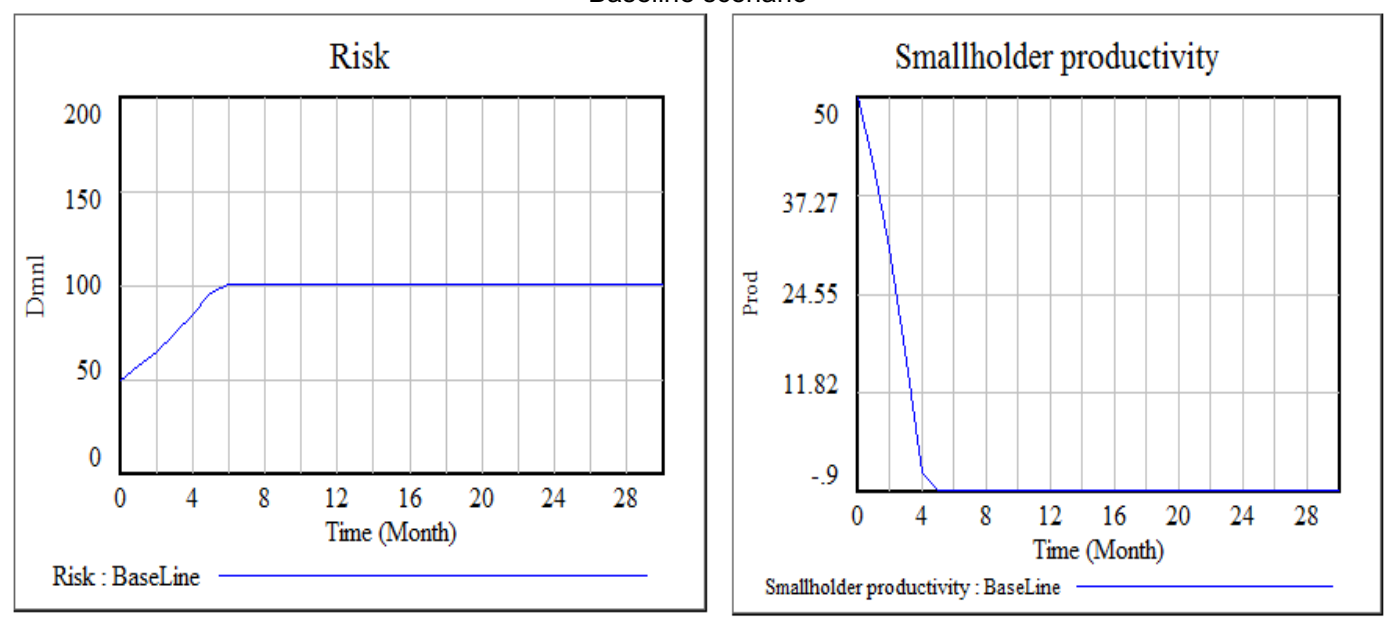

Starting off at a stock of 50 out of 100 for both risk and SHF productivity, it is observed that, within six months, risk will peak at 100 (see left-hand graph in Figure 11). Because open-market conditions have been assumed, it can be inferred that no banks will be prepared to supply products to SHFs within the same time frame. From the survey, we know that only the banks concerned indicated that they were prepared to make loans to SHFs, at this stage on account of philanthropic reasons and brand image, and not because of open-market conditions, in which case they would, like the other banks, not be offering services to SHFs. 
So this raises the question: What scenarios should be examined to show the levels at which turnaround is expected and at which risk continually decreases, thereby increasing SHF productivity? In other words, how much stimulation does the market need from outside, say from government, in order to tip the scale in favour of SHFs. To answer these questions, what-if analysis was used:

1 What is the extent of engagement by banks, insurance companies and retailers that results in a tipping point?

2 What is the minimal engagement required from each of the three sectors to get to the tipping point?

3 Does the interview-indicated readiness of banks and retailers result in a tipping point?

The core variable which was utilised to define the tipping point in favour of SHFs was the level of stock at which risk goes below 50 points. The results pertaining to this variable were observed for each of the three questions above. Such results are outlined in the following section.

\section{Results}

\subsection{Baseline results}

The results from the different what-if analyses are summarised in Table 3. Here, we can already see that the fastest tipping point in favour of SHFs occurs within a very short period and requires each of the three sectors to "pull their weight".

Table 3

Summary results from what-if analysis

\begin{tabular}{|l|c|c|c|c|}
\hline \multicolumn{1}{|c|}{ What-if analysis } & Banks & $\begin{array}{c}\text { Insurance } \\
\text { companies }\end{array}$ & Retailers & $\begin{array}{c}\text { Tipping point achieved (after ... } \\
\text { months) }\end{array}$ \\
\hline 1. Only banks & $80 \%$ & $0 \%$ & $0 \%$ & Yes (14) \\
\hline 2. Only insurance companies & $0 \%$ & $100 \%$ & $0 \%$ & No \\
\hline 3. Only retailers & $0 \%$ & $0 \%$ & $100 \%$ & No \\
\hline 4. Minimum turnaround & $33 \%$ & $33 \%$ & $33 \%$ & Yes (4) \\
\hline 5. Interview results & $65 \%$ & $65 \%$ & $50 \%$ & Yes (0) \\
\hline
\end{tabular}

In the following subsections, we detail the results from each of the above simulations of the five scenarios.

\subsection{Extent of bank, insurance and retailer engagement in order to get to the tipping point?}

Once we set the model such that 80 per cent of SHFs are engaged by the banks, or have access to microloans, a turnaround is observed as shown by the results in Figure 11. There is an initial increase in risk. However, this declines as retailers and traders make use of the elevated productivity owing to bank engagement with a delay. The delay observed in Figure 11 arises from the time it takes for SHFs to increase productivity from the level of bank engagement.

If we set the model such that insurance companies engage 100 per cent in offering microinsurance to SHFs, the risk initially declines because banks will also show an initial inclination to increase their engagement for the first 10 months. However, as shown in Figure 12 and Table 1, because banks decide to disengage after 10 months, as retailers and traders continuously reduce their engagement, the risks increase again and general support drops, with no turnaround in favour of SHFs. 
Figure 11

Banks drive change

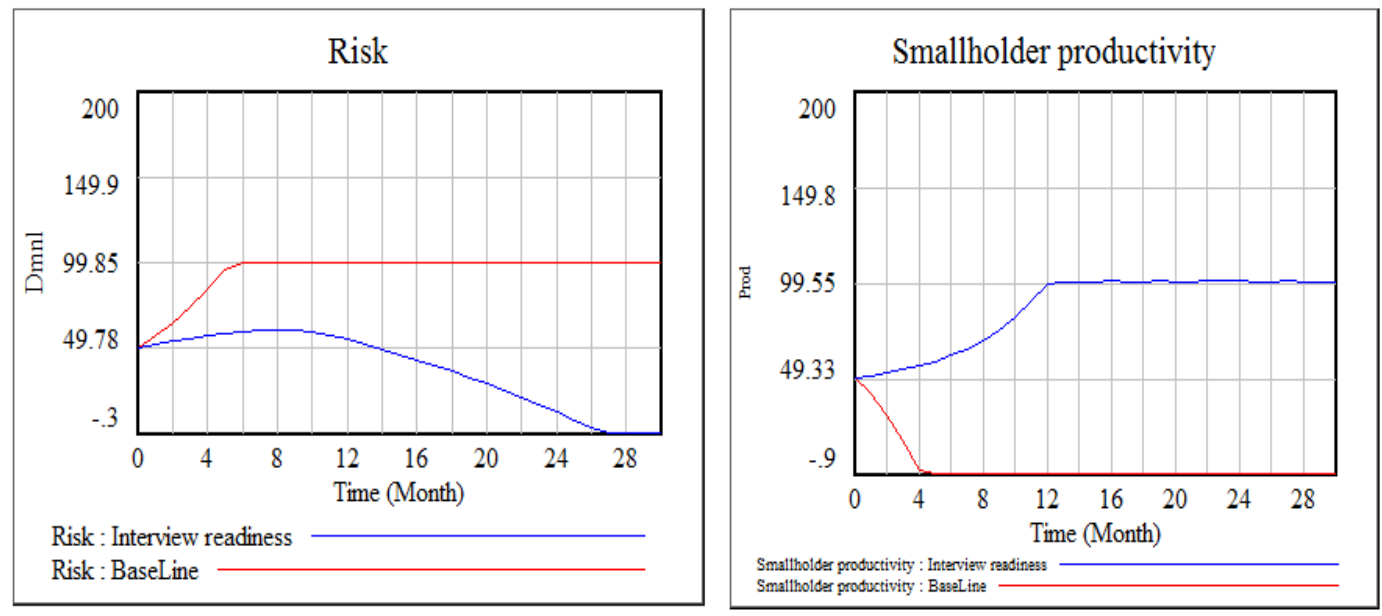

Table 4

Insurance companies drive change

\begin{tabular}{|c|c|c|c|c|c|c|c|}
\hline \multicolumn{3}{|c|}{ Time (MonthBanks } & \multirow[t]{2}{*}{$\wedge$} & \multicolumn{3}{|c|}{ Time (Month)Retailers \& Traders" } & \multirow[t]{2}{*}{$\wedge$} \\
\hline 0 & -3 & -1.5 & & 0 & 0 & 0 & \\
\hline 1 & -2.9606 & -1.5 & & 1 & -0.106003 & -0.879558 & \\
\hline 2 & -2.92268 & -1.5 & & 2 & -0.226792 & -1.95252 & \\
\hline 3 & -2.8866 & -1.5 & & 3 & -0.365978 & -3.26142 & \\
\hline 4 & -2.85281 & -1.5 & & 4 & -0.528055 & -4.85813 & \\
\hline 5 & -2.82186 & -1.5 & & 5 & -0.718612 & -5 & \\
\hline 6 & -2.79446 & -1.5 & & 6 & -0.944605 & -5 & \\
\hline 7 & -2.77147 & -1.5 & & 7 & -1.21469 & -5 & \\
\hline 8 & -2.75396 & -1.5 & & 8 & -1.53963 & -5 & \\
\hline 9 & -2.74328 & -1.5 & & 9 & -1.93282 & -5 & \\
\hline 10 & -2.74109 & -1.5 & & 10 & -2.41093 & -5 & \\
\hline 11 & -2.74947 & -1.5 & & 11 & -2.9947 & -5 & \\
\hline 12 & -2.77099 & -1.5 & & 12 & -3.70993 & -5 & \\
\hline 13 & -2.80887 & -1.5 & & 13 & -4.58874 & -5 & \\
\hline 14 & -2.8635 & -1.5 & & 14 & -5 & -5 & \\
\hline 15 & -2.92123 & -1.5 & & 15 & -5 & -5 & \\
\hline 16 & -2.98013 & -1.5 & & 16 & -5 & -5 & \\
\hline 17 & -3 & -1.5 & & 17 & -5 & -5 & \\
\hline 18 & -3 & -1.5 & & 18 & -5 & -5 & \\
\hline \multirow[t]{2}{*}{19} & -3 & -1.5 & & 19 & -5 & -5 & \\
\hline & & & $\checkmark$ & 20 & -5 & -5 & $\checkmark$ \\
\hline$<$ & & & & $<$ & & & \\
\hline
\end{tabular}

The retailers and traders are not willing to engage in this scenario, as insurance alone does not increase productivity. Productivity increases with variables such as credit, education and access to land, not insurance, as insurance does not directly influence the productivity of the crop. It only does so in the case of a claim, such as for losses incurred as a result of drought, and the then available cash to continue production.

When, however, we set the model such that retailers show an initial preparedness to engage 100 per cent with SHFs, this engagement quickly ends up with complete disengagement, as shown in the right-hand table in Table 5 and in Figure 13. 
Figure 12

Results of insurance companies driving change



Risk : Interview readiness Risk : BaseLine



Smallholder productivity : BsseL ine

Table 5

Retailers drive change

\begin{tabular}{|c|c|c|c|c|c|c|c|}
\hline \multirow{2}{*}{\multicolumn{3}{|c|}{ Time (MonthInsurances }} & \multirow{3}{*}{$\hat{\wedge}$} & \\
\hline & & & & \multicolumn{3}{|c|}{ Time (MonthBanks } & \multirow[t]{2}{*}{$\wedge$} \\
\hline 0 & -5 & -5 & & 0 & -5 & -1.5 & \\
\hline 1 & -5 & -5 & & 1 & -5 & -1.5 & \\
\hline 2 & -5 & -5 & & 2 & -5 & -1.5 & \\
\hline 3 & -5 & -5 & & 3 & -5 & -1.5 & \\
\hline 4 & -5 & -5 & & 4 & -5 & -1.5 & \\
\hline 5 & -5 & -5 & & 5 & -5 & -1.5 & \\
\hline 6 & -5 & -5 & & 6 & -5 & -1.5 & \\
\hline 7 & -5 & -5 & & 7 & -5 & -1.5 & \\
\hline 8 & -5 & -5 & & 8 & -5 & -1.5 & \\
\hline 9 & -5 & -5 & & 9 & -5 & -1.5 & \\
\hline 10 & -5 & -5 & & 10 & -5 & -1.5 & \\
\hline 11 & -5 & -5 & & 11 & -5 & -1.5 & \\
\hline 12 & -5 & -5 & & 12 & -5 & -1.5 & \\
\hline 13 & -5 & -5 & & 13 & -5 & -1.5 & \\
\hline 14 & -5 & -5 & & 14 & -5 & -1.5 & \\
\hline 15 & -5 & -5 & & 15 & -5 & -1.5 & \\
\hline 16 & -5 & -5 & & 16 & -5 & -1.5 & \\
\hline 17 & -5 & -5 & & 17 & -5 & -1.5 & \\
\hline 18 & -5 & -5 & & 18 & -5 & -1.5 & \\
\hline 19 & -5 & -5 & & 19 & -5 & -1.5 & \\
\hline & & & $v$ & & & & $\checkmark$ \\
\hline$<$ & & & & $<$ & & & \\
\hline
\end{tabular}

\begin{tabular}{|c|c|c|}
\hline \multicolumn{3}{|c|}{ Time (Month"Retailers \& Traders" } \\
\hline 0 & 5 & 0 \\
\hline 1 & 5 & -0.879558 \\
\hline 2 & 5 & -1.95252 \\
\hline 3 & 5 & -3.26142 \\
\hline 4 & 5 & -4.85813 \\
\hline 5 & 5 & -5 \\
\hline 6 & 5 & -5 \\
\hline 7 & 5 & -5 \\
\hline 8 & 5 & -5 \\
\hline 9 & 5 & -5 \\
\hline 10 & 5 & -5 \\
\hline 11 & 5 & -5 \\
\hline 12 & 5 & -5 \\
\hline 13 & 5 & -5 \\
\hline 14 & 5 & -5 \\
\hline 15 & 5 & -5 \\
\hline 16 & 5 & -5 \\
\hline 17 & 5 & -5 \\
\hline 18 & 5 & -5 \\
\hline 19 & 5 & -5 \\
\hline 20 & 5 & -5 \\
\hline$<$ & & \\
\hline
\end{tabular}

This is a limitation of the modelling. There should be some form of willingness to change on the part of banks and insurance companies that is linked to retailers' and traders' willingness to change. In the interviews during data collection, banks clearly indicated that there was disengagement from their side because SHFs had no access to markets in order to sell their products and thereby repay their debt to the banks. This, in turn, implies that, when SHFs have access to markets and therefore have cash to pay back their loans, there will be some level of interest by banks in engaging with SHFs and not no interest as initially assumed by us and represented in the model. 
Figure 13

Retailers drive change

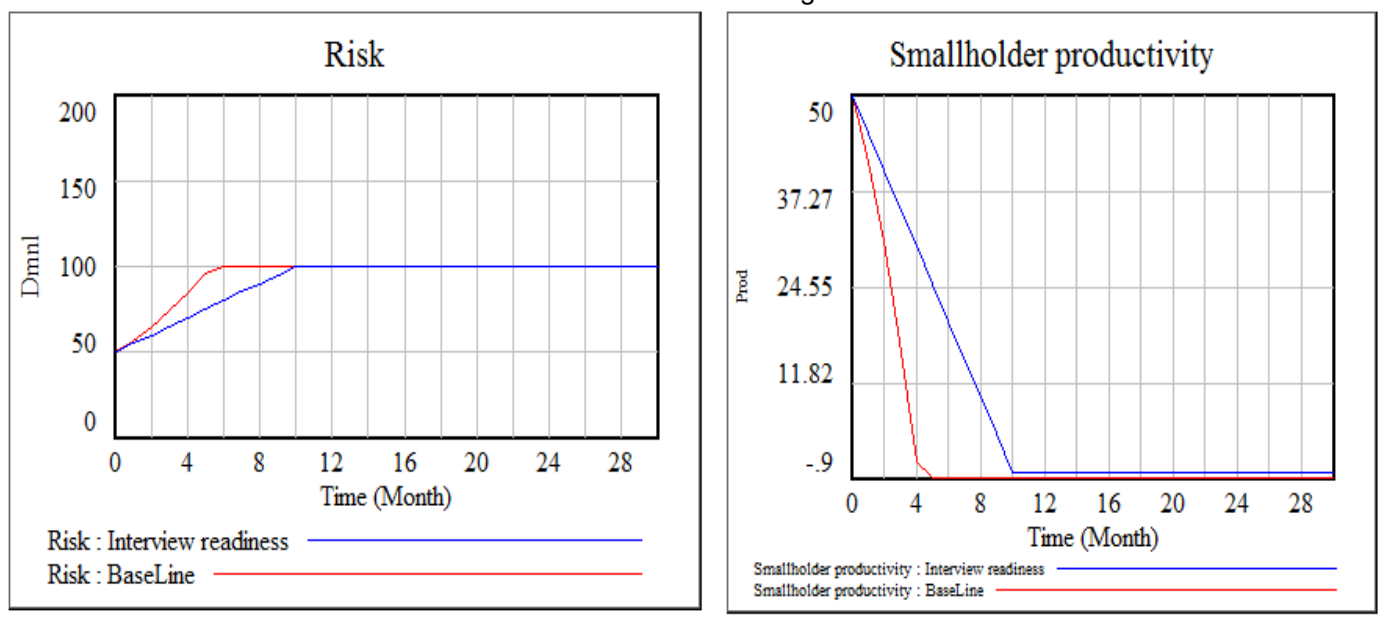

The missing research question, here, that would need to be added to the previous interviews so as to obtain complete data for modelling is: How much will banks and insurance companies engage with SHFs if retailers are prepared to buy from SHFs? Future iterations of this model should then consider this newly collected data.

\subsection{What is the minimal engagement required from each of the three sectors in order to get to the tipping point?}

Risk will gradually disappear over two years when we set the model such that all three sectors namely banks, insurance companies and retailers/traders, engage with SHFs at a level of 33 per cent - in which case the tipping-point risk reducing in favour of SHFs starts within three months, as can be observed from the right-hand graph in Figure 14.

Figure 14

Minimal engagement to turnaround
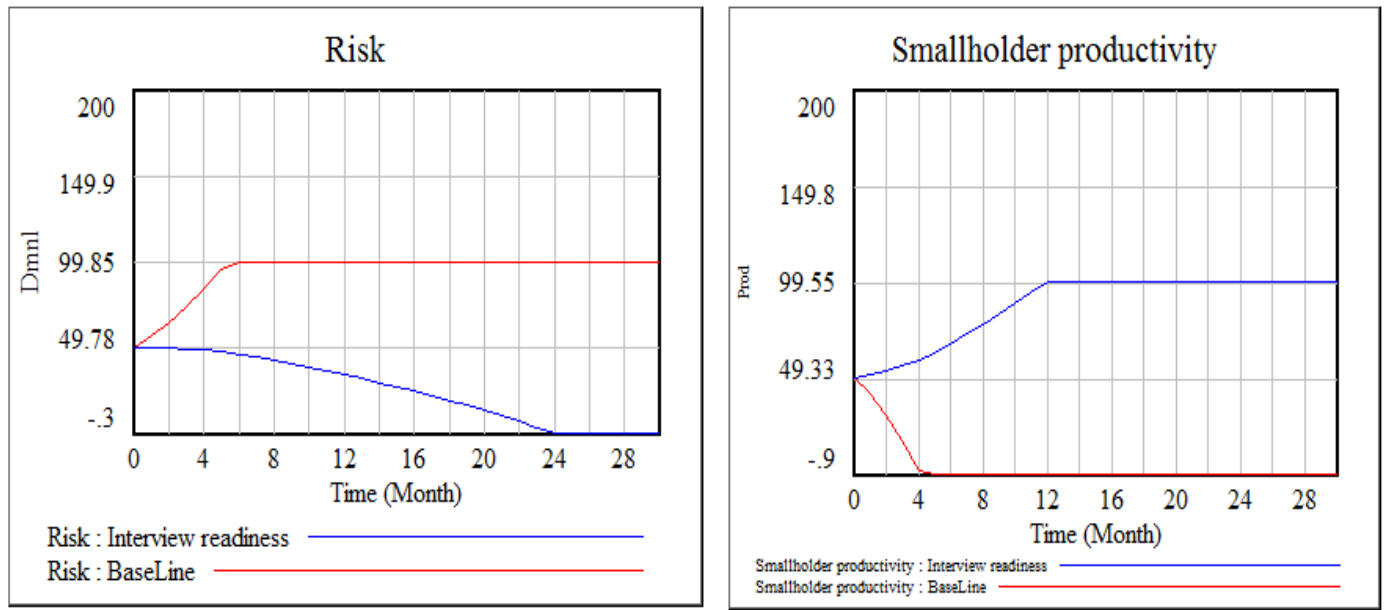

\subsection{Does the interview-indicated readiness of banks and retailers result in the} tipping point?

The interview data used shows that banks and retailers are prepared to increase their engagement to 65 per cent (banks) and 50 per cent (retailers) should there be some form of concerted effort to 
change the system in favour of SHFs. What would happen if this were simulated?

Setting the model accordingly, the simulated results are very clear: within a very short period, namely five months, risk would disappear and SHF productivity would maximise, resulting in an immediate tipping point in favour of SHFs, as observed in Figure 15.

Figure 15

Results from interview-indicated readiness
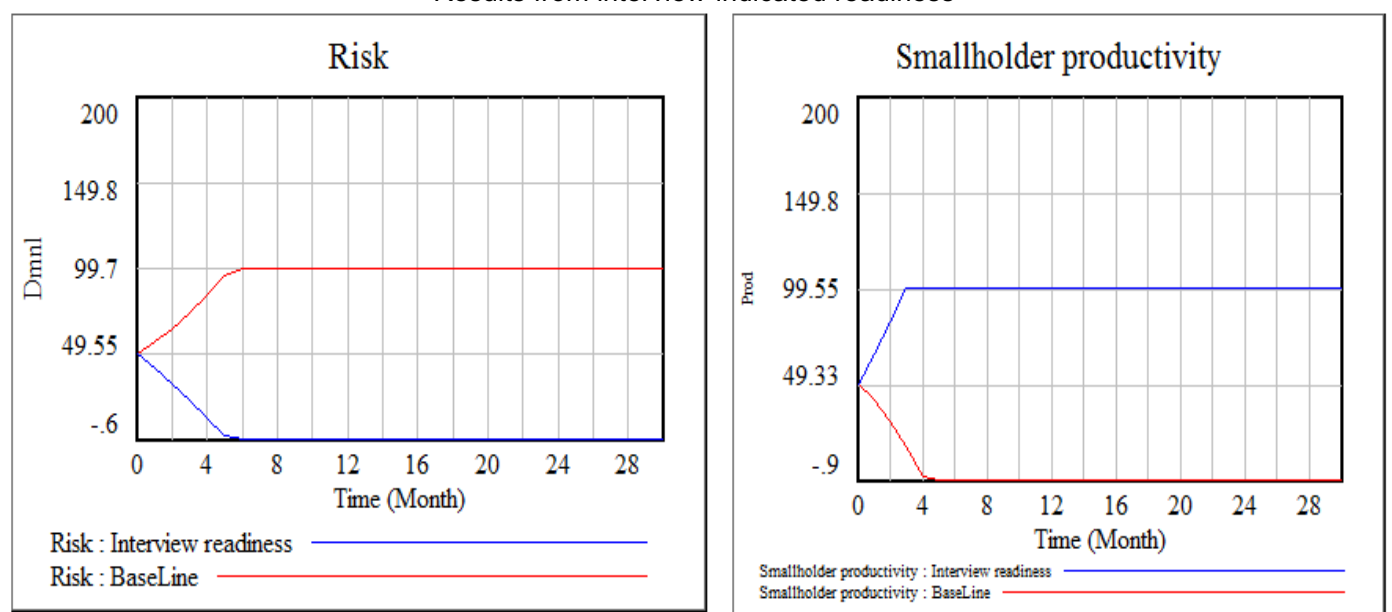

\section{Conclusion}

In the literature review, a number of challenges facing SHFs were highlighted for further investigation through the use of system dynamics. The purpose was to examine if there were opportunities for value chains to become inclusive of SHFs. While interest on the part of VCPs exists, there is actually no real engagement, as the VCPs believe that there are too many challenges facing SHFs to validate such engagement. The results, however, show that, if all VCPs engage SHFs, this would solve a host of SHF challenges and result in a positive impact allowing SHFs to engage with modern agricultural value chains. However, what we were also able to define were the limitations of this model and future possibilities extend the model.

\subsection{Shortfalls of the model and the data}

From the interviews, it was observed that traders will be less willing to engage with SHFs than retailers, and that this is likely due to branding purposes, something which is not reflected in the current model.

The assumptions as to how each value-chain element influences SHF productivity, and by how much, are not well represented. The interview questions never asked by how much these variables influence productivity. Therefore, the model assumes that each of the variables equally influences SHF productivity, yet the reality might very well be different and weights might need to be added to each of the variables in order to represent a more realistic scenario.

Education has a huge influence on the productivity of SHFs, and this should be included in future modelling. For example, even if banks were to extend as much credit to SHFs as they wanted to, the effect of bank engagement would be zero if, in turn, SHFS did not know how to convert this credit into productivity. So, for this model, the assumption is that SHFs have all the education necessary to effectively become productive. Therefore, further research should be conducted that specifically includes this variable in the stocks and flows in order to show farmlevel productivity and potential failure of the system even if large value-chain participants are willing to engage. 
One dynamic hypothesis is that bank engagement influences insurance engagement, and vice versa. However, the stock-and-flow diagram only considers that insurance companies influence banks' decisions on engagement and not that banks influence insurance companies' level of engagement. This reinforcing feedback loop is likely to change the modelling results and therefore this needs to be examined.

Similarly, the interactions between retailer engagement with banks and insurance companies was not accounted for in the model. If retailers are prepared to buy, and pay for, crops from SHFs, banks, for example, will be interested in extending loans to such SHFs, even if such loans are only small. This effect will influence the delay time in which the risk will reduce - in which case the financial institutions will directly communicate with the retailers.

The influence of FICA and the Credit Act, of grant-funding, and of access to fertile land on risk and productivity has not been considered in this model and could be useful if added in future. An additional question remains, that is, whether the model sufficiently represents the cash required by SHFs and whether exogenous variables like FICA and the Credit Act limit banks and insurance companies to such an extent that it will never be viable within the current operational-management environment to extend services to SHFs.

The effect that information and communications technology (ICT) can have in streamlining operations for banks and insurance companies, and making provision for Acts and regulations that nevertheless ensure viability for banks and insurance companies, was not considered. Also, this model does not consider other practical barriers experienced by SHFs, such as the impact of communal grazing on yield, instances where uncontrolled cattle enter fields of crops, or the theft of crops before harvesting in poor rural areas where smallholder farming mostly occurs. NGOs, government organisations, universities, and agricultural colleges were also not included in this model, because the intention was to consider economic agents in an effort to find potential nerve points of change which business can drive and government policy can use to drive change in favour of an inclusive economic system for SHFs.

Endnote

* Corresponding author: wolfgang@mysmart.farm

\section{References}

ADHYA, T., SHARMA, P. \& GOGOI KUMAR, A. 2009. Mitigating greenhouse gas emission from agriculture. In; Climate change and crops. Berlin, Heidelberg: Springer-Verlag:329-344.

ALIBER, M. \& HALL, R. 2010. Programme to support pro-poor policy development (PSPPD).

Development of evidence-based policy around small-scale farming.

ALIBER, M. \& HALL, R. 2012. Support for smallholder farmers in South Africa: Challenges of scale and strategy. Development Southern Africa, 29(4):548-562.

ALIBER, M. \& HART, T.G. 2009. Should subsistence agriculture be supported as a strategy to address rural food insecurity? Agrekon, 48(4):434-458.

ALMOND, F.R. \& HAINSWORTH, S.D. 2005. Beyond agriculture - making markets work for the poor: Proceedings of an international seminar in Westminster, London: Crop Post-Harvest Research Programme.

ALTIERI, M. 2009. Agroecology, small farm and food sovereignty. Monthly Review, 61(3):102-113.

Agroecologically efficient agricultural systems for smallholder farmers: Contributions to food sovereignty. Agronomy for Sustainable Development, 32(1):1-13. http://link.springer.com/10.1007/s13593-011-0065-6 [accessed April 2014].

ALTIERI, M. \& NICHOLLS, C.I. 2005. Chapter 7: Enhancing the productivity of Latin America. Traditional peasant farming. In: Agroecology and the search for a truly sustainable agriculture.

ALTMAN, M., HART, T.B.G. \& JACOBS, P.T. 2010. Household food security status in South Africa. Agrekon, 48(4):345-361.

ANDERSSON, C.I.M., KIRIA, C.G., QAIM, M. \& RAO, E.J.O.2013. Following up on smallholder farmers and supermarkets. Global Food Discussion Papers, 23:1-29. 
BAIPHETHI, M.N. \& JACOBS, P.T. 2009. The contribution of subsistence farming to food security in South Africa. Agrekon, 48(4):459-482.

BERNSTEIN, H. 2013. Food sovereignty: A sceptical view of food. http://www.iss.nl/fileadmin/ASSETS/ iss/Research_and_projects/Research_networks/ICAS/ICAS_Review_Paper_4_Bernstein.pdf [accessed April 2014].

BIÉNABE, E., VERMEULEN, H. \& BRAMLEY, C. 2011. The food "quality turn" in South Africa: An initial exploration of its implications for small-scale farmers' market access. Agrekon, 50(1):36-52.

BLIGNAUT, J.N., KNOT, J., SMITH, H., NKAMBULE, N., CROOKES, D., SAKI, A., DRIMIE, S., MIDGLEY, S., DE WIT, M., VON LOEPER, W.J. \& STRAUSS, J. 2015. Promoting and advancing the uptake of sustainable, regenerative, conservation agricultural practices in South Africa with a specific focus on dryland maize and extensive beef production. Key findings and recommendations. 1 booklet: ASSET Research, Pretoria.

BLIGNAUT, J.N., DE WIT, M.P., KNOT, J., MIDGLEY, S., CROOKES, D.J., DRIMIE, S. \& NKAMBULE, N.P. 2014. Sustainable agriculture: A viable option for enhanced food and nutritional security and a sustainable productive resource base in South Africa: An investigation. Baseline Review. Prepared for the Development Bank Southern Africa. Pretoria: ASSET Research.

BRYAN, E., DERESSA, T.T., GBETIBOUO, G.A. \& RINGLER, C. 2009. Adaptation to climate change in Ethiopia and South Africa: Options and constraints. Environmental Science and Policy, 12(4):413-426. doi: 10.1016/j.envsci.2008.11.002.

CAMBRIDGE UNIVERSITY (INSTITUTE FOR MANUFACTURING). Porter's value chain. http://www.ifm.eng.cam.ac.uk/research/dstools/value-chain-/ [accessed September 2014].

CHASSY, A.W., BUI, L., RENAUD, E.N.C., VAN HORN, M. \& MITCHELL, A.E. 2006. Three-year comparison of the content of antioxidant microconstituents and several quality characteristics in organic vs conv. Journal of Agricultural and Food Chemistry, 54(21):8244-8252. doi: 10.1021/jf060950p.

CLEVELAND, C. \& KAUFMANN, R. 1986. Energy and resource quality. New York: Wiley Interscience. COGHLAN, A. 2006. More crops for Africa as trees reclaim the desert. New Scientist, 192(2573):11.

CORMACK, B. \& METCALFE, P. 2000. Energy use in organic farming systems. London: Ministry of Agriculture, Fisheries and Food.

DELATE, K. \& CAMBARDELLA, C. 2004. Organic production. Agroecosystem performance during transition to certified organic grain production. Agronomy Journal, 96:1288-1298.

DELGADO, C.L. 1999. Sources of growth in smallholder agriculture integration of smallholders with processors in Sub-Saharan Africa: The role of vertical and marketers of high value-added items. Agrekon, 38(sup001):165-189.

DE SCHUTTER, O. \& SCHUTTER, D. 2009. The right to food: Fighting for adequate food in a global crisis. Harvard Itnernational Review, 31(2):1-6.

DIAZ, R.J. \& ROSENBERG, R. 2008. Spreading dead zones and consequences for marine ecosystems. Science (New York, N.Y.), 321(5891):926-929. http://www.ncbi.nlm.nih.gov/pubmed/18703733 [accessed April 2014].

EDWARDS, S. 2004. Greening Ethiopia series. Science in Society, 23:4-8.

EWERS, R.M. \& DIDHAM, R.K. 2008. Pervasive impact of large-scale edge effects on a beetle community. Proceedings of the National Academy of Sciences, 105(14):4-7.

FAOSTAT, 2014. Food and Agriculture Organization (FAO) of the UN. http://faostat.fao.org/ [accessed March 2015].

FISCHER, J., BROSI, B., DAILY, G.C., EHRLICH, P.R., GOLDMAN, R., GOLDSTEIN, J., LINDENMAYER, D.B., MANNING, A.D., MOONEY, H.A., PEJCHAR, L., RANGANATHAN, J. \& TALLIS, H. 2008. Should agricultural policies encourage land sparing or wildlife-friendly farming? Frontiers in Ecology and the Environment, 6(7):380-385. doi: 10.1890/070019.

HEIJDEN, V. \& VINK, N. 2013. Good for whom? Supermarkets and small farmers in South Africa - a critical review of current approaches to increasing access. Agrekon, 52(1):68-86.

HENDRIKS, S. 2013. South Africa's National Development Plan and New Growth Path. Agrekon, 52(3): 1-17. http://www.tandfonline.com/doi/abs/10.1080/03031853.2013.821741 [accessed March 2014]. 
HENDRIKS, S. 2014. Food security in South Africa: Status quo and policy imperatives. Agrekon, 53(2):1-24. http://www.scopus.com/inward/record.url?eid=2-s2.0-84903135751\&partnerID=tZOtx3y1 [accessed March 2015].

HEPPERLY, P. 2003. Organic farming sequesters atmospheric carbon and nutrients in soils. http://www.newfarm.org/depts/NFfield_trials/1003/carbonwhitepaper.shtml [accessed November 2014]. HUBER, M., REMBIAŁKOWSKA, E., ŚREDNICKA, D., BÜGEL, S. \& VAN DE VIJVER, L.P.L. 2011. Organic food and impact on human health: Assessing the status quo and prospects of research. NJAS Wageningen Journal of Life Sciences, 58(3-4):103-109. doi: 10.1016/j.njas.2011.01.004.

IAASTD (International Assessment of Agricultural Knowledge, Science and Technology for Development). 2009. Agriculture at a crossroads: Sub-Saharan Africa (SSA) report. Washington DC.

JUNE, S. \& GÜNTHER, F. 2000. Vulnerability in agriculture: Energy use, structure and energy futures. In Paper presented at the INES Conference, KTH Stockholm. http://etnhum.etn.lu.se/ fg/written/stuff/ines/ INES.pdf [accessed June 2014].

KIRSTEN, J.F. \& VAN ZYL, J. 1998. Defining small-scale farmers in the South African context. Routledge Taylor \& Francis, 37(4):551-562.

LABADARIOS, D., MCHIZA, Z.J.-R., STEYN, N.P., GERICKE, G., MAUNDER, E.M.W., DAVIDS, Y. D. \& PARKER, W. 2011. 'Food security in South Africa: a review of national surveys.' Bulletin of the World Health Organization, 89(12):891-899. doi: 10.2471/BLT.11.089243.

LAL, R. 2004. Soil carbon sequestration impacts on global climate change and food security. Science, 304 (5677):1623-1627.

LAL, R., NEGASSA, W. \& LORENZ, K. 2015. Carbon sequestration in soil. Current Opinion in Environmental Sustainability, 15(C):79-86. http://dx.doi.org/10.1016/j.cosust.2015.09.002.

LASCO, R., SALES, R., EXTRELLA, R., SAPLACO, S., CASTILLO, A., CRUZ, R. \& PULHIN, F. 2001. Carbon stock assessment of two agroforestry systems in a tropical forest reserve in the Philippines. The Philippine Agriculturist, 84:401-407.

LETOURNEAU, D.K., ARMBRECHT, I., RIVERA, B.S., LERMA, J.M., CARMONA, E.J., DAZA, M.C., ESCOBAR, S., GALINDO, V., GUTIÉRREZ, C., LÓPEZ, S.D., MEJÍA, J.L., RANGEL, A.M.A., RANGEL, J.H., RIVERA, L., SAAVEDRA, C.A., TORRES, A.M., TRUJILLO, A.R., ARMONA, N.E.Z.C., AZA, M.A.C.O.D., SCOBAR, S.E.E. \& ALINDO, V.I.C.G. 2011. Does plant diversity benefit agroecosystems? A synthetic review. Ecological applications: A Publication of the Ecological Society of America, 21(1):9-21. http://www.ncbi.nlm.nih.gov/pubmed/21516884 [accessed June 2016].

LIM, L. 2002. Organic agriculture fights back. Science in Society, 16:30-32.

LINNEROOTH-BAYER, J. \& MECHLER, R. 2007. Insurance for assisting adaptation to climate change in developing countries: A proposed strategy. Climate Policy, 6(2006):1-17.

LITHOURGIDIS, A.S., DORDAS, C.A., DAMALAS, C.A. \& VLACHOSTERGIOS, D.N. 2011. Review article on annual intercrops: An alternative pathway for sustainable agriculture. Australian Journal of Crop Science, 5(4):396-410.

LOVE, D., TWOMLOW, S., MUPANGWA, W., VAN DER ZAAG, P., GUMBO, B. \& NYABEZE, W. 2006. Implementing the millennium development food security goals - challanges of the Southern African context. Physics and Chemistry of the Earth, 31(15):731-737. doi: 10.13748/j.cnki.issn1007-7693. 2014.04.012.

MAGINGXA, L.L., ALEMU, Z.G. \& VAN SCHALKWYK, H.D. 2009. Factors influencing access to produce markets for smallholder irrigators in South Africa. Development Southern Africa, 26(1):47-58. http://www.tandfonline.com/doi/abs/10.1080/03768350802640081.

MAHLOGEDI, L. \& THINDISA, V. 2014. Participation by smallholder farming entrepreneurs in agroprocessing activities in South Africa. Johannesburg.

MATSON, P.A. \& VITOUSEK, P.M. 2006. Agricultural intensification: Will land spared from farming be land spared for nature? Conservation Biology, 20(3):709-710. http://doi.wiley.com/10.1111/j.15231739.2006.00442.x [accessed May 2014].

MEADOWS, D.H. 1989. System dynamics meets the press. System Dynamics Review, 5(1):69-80.

MEADOWS, D.H. 2009. Thinking in systems. D. Wright, ed., Earthscan.

MEDARD, G. 1981. Empty breadbasket? The coming challenge to America's food supply and what we can do about it. Emmaus, Pa: Rodale Press. 
MIDGLEY, S., DRIMIE, S., LOEPER, W., VON, MUDAVANHU, S., BLIGNAUT, J., SMITH, H. \& DE WIT, M. 2015. Implications for a future agrarian structure in South Africa based on conservation and sustainable agriculture : alignment of a multi- institutional and multi-policy landscape Key findings and recommendations (cont .), (1):1-21. doi: 10.13140/RG.2.1.2070.3203.

MITCHELL, A.E., HONG, Y.-J., KOH, E., BARRETT, D.M., BRYANT, D.E., DENISON, R.F. \&

KAFFKA, S. 2007. Ten year comparison of the influence of organic and conventional crop on flavonoids. Journal of Agricultural and Food Chemistry, 55(15):6154-6159. doi: 10.1021/jf070344+.

MODISELLE, S., VERSCHOOR, A.-J. \& STRAUSS, J. 2015. Western Cape wheat producers and conservation agriculture technology uptake. GrainSA:50-51.

NELSON, G.C., ROSEGRANT, M.W., KOO, J., ROBERTSON, R., SULSER, T., ZHU, T., RINGLER, C., MSANGI, S., PALAZZO, A., BATKA, M., MAGALHAES, M., VALMONTE-SANTOS, R., EWING, M. AND LEE, D. 2009. Climate change: Impact on agriculture and costs of adaptation. Washington DC: International Food Policy Research Institute.

NGOMANE, T., THOMSON, J.S. \& RADHAKRISHNA, R.B. 2002. Public sector agricultural extension system in the Nothern Provinceof South Africa: A system undergoing transformation. The Journal of Agricultural Education and Extension, 9(3):31-37.

ORTMANN, G.F. \& KING, R.P. 2007. Agricultural cooperatives II: Can they facilitate access of small-scale farmers in South Africa to input and product markets? Agrekon, 46:2(March 2015):219-244.

PAGE, S. \& SLATE, R. 2003. Small producer participation in global food systems: Policy opportunities and constraints. Development Policy Review, 21(5-6):641-654.

PENGUE, W., BRIEN, M.O., GARCIA, F., SIMS, R., ROBERT, W., KAUPPI, L., SWILLING, M., HERRICK, J., COSTELLO, C., ENRÍQUEZ, M.A., GOWDY, J., HERRERO, C., ENRIQUE, T., SICARD, L., LAMBIN, E., LAVELlE, P., MORELlO, J., NWAJIUBA, C., STENGEL, O. \& VIGLIZZO, E. 2013. Assessign Global Land Use: Balancing consumption with sustainble supply. Paris: UNEP - International resource Panel.

PERFECTO, I. \& VANDERMEER, J. 2008. Biodiversity conservation in tropical agroecosystems: A new conservation paradigm. Annals of the New York Academy of Sciences, 1134:173-200. http://www.ncbi.nlm.nih.gov/pubmed/18566094 [accessed May 2014].

PIMENTEL, D., HARVEY, C., RESOSUDARMO, P., SINCLAIR, K., KURZ, D., MCNAIR, M., CRIST, S., SHPRITZ, L., FITTON, L., SAFFOURI, R. \& BLAIR, R. 1995. Environmental and economic costs of soil erosion and conservation benefits. Science, 267(5201):1117-1123.

PINGALI, P.L. \& PARDEY, P.G. 2010. Reassessing international agriculture research for food and agriculture. Montpellier, France.

PONISIO, L.C., M'GONIGLE, L.K., MACE, K.C., PALOMINO, J., DE VALPINE, P. \& KREMEN, C. 2014. Diversification practices reduce organic to conventional yield gap. Proceedings of the Royal Society $B$ : Biological Sciences, 282(1799):20141396-20141396. doi: 10.1098/rspb.2014.1396.

PRETTY, J. 2002. Agri-culture: Reconnecting people, land and nature. London: Earthscan.

PRETTY, J. 2008. Agricultural sustainability: Concepts, principles and evidence. Philosophical Transactions of the Royal Society of London, 363(1491):447-465. http://www.pubmedcentral.nih.gov/articlerender.fcgi? artid $=2610163 \&$ tool $=$ pmcentrez\&rendertype $=$ abstract [accessed April 2014].

RAICH, J. \& SCHELSINGER, W. 1992. The global carbon dioxide flux in soil respiration and its relationship to vegetation and climate. Tellus, 44B:81-99.

RAMAILA, M., MAHLANGU, S. \& DU TOIT, D. 2011. Agricultural productivity in South Africa: Literature review. Pretoria: Directorate Economic Service Production Economics Unit.

REICOSKY, D.C. 1997. Tillage-induced $\mathrm{CO}_{2}$ emission from soil. Nutrient Cycling in Agroecosystems, 49:273-285.

RES, M., DANGOUR, A.D., ALLEN, E., LOCK, K. \& UAUY, R. 2010. Nutritional composition \& health benefits of organic foods - using systematic reviews to question the available evidence. The Indian journal of medical research, 131(April):478-80. http://www.ncbi.nlm.nih.gov/pubmed/20424296 [accessed November 2014].

REUSSER, L., BIERMAN, P. \& ROOD, D. 2015. Quantifying human impacts on rates of erosion and sediment transport at a landscape scale. Geology, (2):1-4. http://geology.gsapubs.org/cgi/doi/ 10.1130/G36272.1 [accessed January 2015]. 
ROBERTSON, G.P. \& VITOUSEK, P.M. 2009. Nitrogen in agriculture: Balancing the cost of an essential resource. Annual Review of Environment and Resources, 34(1):97-125. http://www.annualreviews.org/ doi/abs/10.1146/annurev.environ.032108.105046 [accessed May 2014].

ROCKSTRÖM, J., STEFFEN, W., NOONE, K., PERSSON, Å., CHAPIN, F.S., LAMBIN, E.F., LENTON, T.M., SCHEFFER, M., FOLKE, C. \& JOACHIM, H. 2009. Planetrary boundaries: Exploring the safe operating space for humanity. Vasa:1-36. doi: 10.1029/2006GL027546.

RODALE INSTITUTE. 2012. Nutritional value of fruits, veggies is dwindling. Rodale Institute. http://www.nbcnews.com/id/37396355/ns/health-diet_and_nutrition/t/nutritional-value-fruits-veggiesdwindling/\#.U4SdkXKSySp [accessed May 2014].

RODALE INSTITUTE. 2014. Regenerative organic agriculture and climate change: A down-to-earth solution to global warming. Kutztown.

SANHANES-1. 2013. The South African national health and nutrition examination survey. Cape Town: HSRC Press.

SCHLESINGER, W. \& ANDREWS, J. 2000. Soil respiration and the global carbon cycle. Biogeochemistry, 48(1):7-20. http://link.springer.com/article/10.1023/A:1006247623877 [accessed April 2016].

SCHROEDER, P. 1991. Agroforestry systems: Integrated land use to store and conserve carbon. Climate Research, 3:53-60.

SMITH, P., BUSTAMANTE, M., AHAMMAD, H., CLARK, H., DONG, H. \& HABERL, H. 2014. Chapter 11, Agriculture, Forestry and Other Land Use (AFOLU). Berlin: Intergovernmental Panel on Climate Change.

TOPP, C.F.E., WANG, W., CLOY, J.M., REES, R.M. \& HUGHES, G. 2013. Emissions from Agricultural soils. Biochemistry, 48(1):972-987. doi: 10.3390/e15030972.

UNCTAD. 2013. Trade and environment review - wake up before it is too late. Geneva: United Nations Conference on Trade and Development.

UNEP. 2011. Towards a green economy: Pathways to sustainable development and poverty eradication. StMartin-Bellevue, France: United Nations Environment Programme. www.unep.org/greeneconomy [accessed March 2014].

UNEP-UNCTAD. 2007. Organic agriculture and food security in Africa. Geneva \& New York. unctad.org/en/docs/ditcted200715_en.pdf [accessed March 2014].

VOLAKAKIS, N., SEAL, C., SANDERSON, R., DOMINIKA, S., STEWART, G.B., BENBROOK, C., BIAVATI, B., MARKELLOU, E., GIOTIS, C., TAHVONEN, R., GROMADZKA-OSTROWSKA, J., REMBIAŁKOWSKA, E., SKWARŁO-SON, K., NIGGLI, U., NICOT, P., LEIFERT, C., BARAŃSKI, M., SREDNICKA-TOBER, D., SKWARŁO-SOŃTA, K. \& JANOVSKÁ, D. 2014. Higher antioxidant and lower cadmium concentrations and lower incidence of pesticide residues in organically grown crops: A systematic literature review and meta-analyses. The British Journal of Nutrition:1-18. doi: 10.1017/S0007114514001366.

VON LOEPER, W.J. 2015. Maize agricultural value chain challenges facing smallholder farmers and conservation agriculture in South Africa. Stellenbosch.

WIGGINS, S. 2009. Can the smallholder model deliver poverty reduction and food security for a rapidly growing population in Africa? FAC Working Paper, No. 8 July 2009. Brighton: Futures Agriculture Consortium, IDS.

WOOD, S. \& COWIE, A. 2004. A review of greenhouse gas emission factors for fertiliser production.: http://www.joanneum.ac.at/iea-bioenergytask38/publications/GHG_Emission_Fertilizer Production_July2004.pdf [accessed August 2014].

ZIERVOGEL, G. 2004. Targeting seasonal climate forecasts for integration into household level decisions: The case of smallholder farmers in Lesotho. The Geographical Journal, 170(1):6-21. 


\section{Modelling tables}

\section{$1.1 \quad$ Table of I influence on $B$}

\begin{tabular}{|c|c|}
\hline-5 & 0 \\
\hline 0 & 0 \\
\hline 5 & 0.2 \\
\hline
\end{tabular}

Equation: $[(-5,-0.3)-(5,0.3)],(-5,0),(0,0),(5,0.2)$

\subsection{Table of $R$ influence on $B$}

\begin{tabular}{|c|c|}
\hline 0 & 0.1 \\
\hline 50 & 0 \\
\hline 100 & 0 \\
\hline
\end{tabular}

Equation: $[(0,-0.2)-(100,100)],(0,0.1),(50,0),(100,0)$

\subsection{Table of $R$ influence on I}

\begin{tabular}{|c|c|}
\hline 0 & 0.1 \\
\hline 50 & 0 \\
\hline 100 & 0 \\
\hline
\end{tabular}

Equation: $[(0,-0.2)-(100,1)],(0,0.1),(50,0),(100,0)$

\section{$1.4 \quad$ Table smallholder productivity influence on $R$}

\begin{tabular}{|c|c|}
\hline 0 & 0 \\
\hline 100 & 1 \\
\hline
\end{tabular}

Equation: $[(0,0)-(100,10)],(0,0),(100,1)$

\section{Other important equations}

\subsection{Increase in productivity}

IF THEN ELSE(Smallholder productivity $>100$, 0, IF THEN ELSE(Insurance companies $>0$, Insurance companies, 0)+IF THEN ELSE(Banks $>0$, Banks, 0))+IF THEN ELSE(Cooperatives, logistics, compliance $>0$, Cooperatives, logistics compliance, 0)+IF THEN ELSE(Cash for input products $>0$, Cash for input products, 0 ))

\subsection{Decrease in productivity}

IF THEN ELSE(Smallholder productivity $<0$, 0, IF THEN ELSE(Insurance companies $<0$, -Insurance companies, 0)+IF THEN ELSE(Banks $<0$, -Banks, 0)+IF THEN ELSE(Cooperatives, logistics, compliance $<0$, -Cooperatives, logistics, compliance, 0)+IF THEN ELSE(Cash for input products $<0,-$ Cash for input products, 0 ))

\section{$2.3 \quad$ Retailers and traders}

Max. engagement*"R-Serving"+Max. disengagement*"R-Not serving”

\section{$2.4 \quad$ Risk increase}

IF THEN ELSE(Risk $>=100,0$, IF THEN ELSE(Banks $<=0, \quad-$ Banks, 0)+IF THEN ELSE(Insurance companies $<=0$, -Insurance companies, 0)+IF THEN ELSE("Retailers \& traders" $<=0,-$ "Retailers \& traders", 0))

\section{$2.5 \quad$ Risk decrease}

IF THEN ELSE(Risk $<=0$, 0, IF THEN ELSE(Banks $>0$, Banks, 0)+IF THEN ELSE(Insurance companies $>0$, Insurance companies, 0)+IF THEN ELSE("Retailers \& traders" $>0$, "Retailers \& 
traders", 0))

\subsection{B-Serving}

IF THEN ELSE("B-Initial serving"+I influence on B serving+R influence on B serving >=1, 1, "BInitial serving" + I influence on B serving $+R$ influence on B serving)

\subsection{I-Serving}

IF THEN ELSE(“I-Initial serving”+R influence on I serving $>=1$, 1, "I-Initial serving"+R influence on I serving)

\subsection{Banks}

Max. engagement*“B-Serving"+Max. disengagement*"B-Not serving"

\subsection{Insurance}

Max. engagement*“I-Serving”+Max. disengagement*“I-Not serving” 